\title{
Species Richness, Community Organization, and Spatiotemporal Distribution of Earthworms in the Pineapple Agroecosystems of Tripura, India
}

\author{
Animesh Dey and P. S. Chaudhuri \\ Earthworm Research Laboratory, Department of Zoology, Tripura University, Suryamaninagar, West Tripura 799022, India \\ Correspondence should be addressed to P. S. Chaudhuri; priya_1956@rediffmail.com
}

Received 26 July 2015; Revised 17 December 2015; Accepted 4 January 2016

Academic Editor: L. M. Chu

Copyright (C) 2016 A. Dey and P. S. Chaudhuri. This is an open access article distributed under the Creative Commons Attribution License, which permits unrestricted use, distribution, and reproduction in any medium, provided the original work is properly cited.

\begin{abstract}
The impact that plant communities may have on underground faunal diversity is unclear. Therefore, understanding the links between plants and organisms is of major interest. Earthworm population dynamics were studied in the pineapple agroecosystems of Tripura to evaluate the impact of monoculture plantation on earthworm communities. A total of thirteen earthworm species belonging to four families and five genera were collected from different sampling sites. Application of sample-based rarefaction curve and nonparametric richness estimators reveal $90-95 \%$ completeness of sampling. Earthworm community of pineapple agroecosystems was dominated by endogeic earthworms and Drawida assamensis was the dominant species with respect to its density, biomass, and relative abundance. Vertical distribution of earthworms was greatly influenced by seasonal variations. Population density and biomass of earthworms peaked during monsoon and postmonsoon period, respectively. Overall density and biomass of earthworms were in increasing trend with an increase in plantation age and were highest in the 30-35-year-old plantation. Significant decrease in the Shannon diversity and evenness index and increase in Simpson's dominance and spatial aggregation index with an increase in the age of pineapple plantation were recorded. Soil temperature and soil moisture were identified as the most potent regulators of earthworm distribution in the pineapple plantation.
\end{abstract}

\section{Introduction}

Earthworms are the most important soil biota of agroecosystem where they play a key role in regulating soil fertility and promoting plant growth through nutrient cycling and water infiltration $[1,2]$. Since earthworms account for the highest biomass among tropical soil macrofauna [3], soil quality depends on population density, species diversity, and activity level of earthworm community. Under similar climate conditions, factors that determine distribution and community structure of earthworms may depend on the changes in land use pattern $[4,5]$ as well as plant species composition and the physical and chemical properties of soils within a plant community $[6,7]$. Thus, earthworm population dynamics and the influence of farming practices on earthworms are of particular interest to organic growers [8].
Pineapple (Ananas comosus (L.) Merr.), native to Southern Brazil and Paraguay, was introduced to India by Portuguese in $1548 \mathrm{AD}$ [9]. It is one of the most delicious tropical fruit crops of commercial importance and widely cultivated in the hill slopes of Tripura, checking soil erosion. Crude extracts from fruits, stems, and leaves of pineapples are good sources of various kinds of sugars, organic acids, vitamins, and several proteinase enzymes including bromelains and peroxidases with immunomodulatory, antiinflammatory, antithrombotic, fibrinolytic, antihelminthic, and tumour growth inhibitory properties [10]. The agroclimatic conditions prevailing in Tripura are ideal for the commercial production of its three common varieties, namely, Queen, Kew, and Mauritius.

The role of earthworms in organic matter decomposition as well as building and maintenance of soil structure has 
been well documented for the soils of temperate regions [11]. Although, in tropics, studies on diversity, ecology, and role of earthworms have been carried out in different agroclimatic zones of Indian subcontinent [12-17], there are scanty records on the diversity and distribution of earthworms and their role in the fruit crop plantations [18] of India including its northeastern parts.

The present paper deals with the community composition and spatiotemporal distribution of earthworms in pineapple plantations with reference to the edaphic factors in Tripura. Our hypothesis is that higher density and dominance of earthworms would be associated with monoculture pineapple plantation. The underlying idea is that if a plant species affects earthworms positively (i.e., due to the matter input), presumably the presence of the resource in abundance will likely promote the establishment of earthworms that benefitted from the resource. Earthworms may use the exudates and metabolites of soil where pineapples are cultivated since they are useful in degrading pineapple wastes [19].

\section{Materials and Methods}

2.1. Study Area and Sites. The studies on the earthworm communities were conducted during April 2008-September 2011 in Tripura $\left(22^{\circ} 51^{\prime}-24^{\circ} 32^{\prime} \mathrm{N}\right.$ and $\left.90^{\circ} 10^{\prime}-92^{\circ} 21^{\prime} \mathrm{E}\right)$ having a total area of $10,491 \mathrm{sq} \cdot \mathrm{km}$. The state is almost encircled by Bangladesh except in the north-east where it meets its neighboring states, Assam and Mizoram. The climatic features of the study area are summer (March-May), monsoon (June-September), autumn (October-November), and winter (December-February) with a mean annual rainfall of $2000 \mathrm{~mm}$ and temperature of $25^{\circ} \mathrm{C}$. Sampling of earthworms was done in the pineapple (Ananas comosus var. queen) plantations ( $>15$ years) at different localities, namely, Bamutia, Nandannagar, Shalbagan, Nutannagar, Bishalgarh, Bishramganj, Padmanagar, Jumerdhepa, and Boiragibazar of Tripura. The distance between the studied sites varied within 20-50 km.

Pineapple plantations of different age groups (1-5 years, 15-20 years, and 30-35 years old) were studied to find the variations in the earthworm community structure in different age groups of pineapple plantation because with increase in plantation age, the chemistry of the soils also changes with input of litter quality.

Pineapple cannot tolerate water-logged condition and is thus usually on undulating uplands, locally called tilla. The soils of well-drained pineapple plantations were acidic ( $\mathrm{pH} 4.6-5.5)$ in nature with loamy sand, loam, or sandy loam texture. Nephelium litchi (Sapindaceae) was the most abundant tree of pineapple plantation. Besides this, presence of Mangifera indica (Anacardiaceae) and Cassia tora (Caesalpiniaceae) along with Syzygium cumini (Myrtaceae) and Cassia sophera (Caesalpiniaceae) in the pineapple plantations was remarkable.

2.2. Experimental Design. Earthworms were collected during summer (April-June) and monsoon (July-September) and postmonsoon period of autumn (October) of each year during the study period of 2008-2011 by TSBF soil monolith
$(25 \mathrm{~cm} \times 25 \mathrm{~cm} \times 40 \mathrm{~cm})$ digging method [20]. This method works well in the soils of Tripura where earthworm communities are dominated mainly by endogeic species. A total of 40 widely separated $10 \mathrm{~m} \times 10 \mathrm{~m}$ plots were randomly selected for sampling in study site. A composite sample comprising five TSBF soil monoliths $(25 \mathrm{~cm} \times 25 \mathrm{~cm} \times 40 \mathrm{~cm})$ were taken from the centre and 4 corners of each sampling plot [21]. Thus, a total of 120 samples (600 TSBF monoliths) were taken from each sampling site. All earthworms were collected directly by hand-sorting from vertically stratified four successive strata of $10 \mathrm{~cm}$ depth from the top to the bottom of each soil monolith [22]. Sampling was done only from plain plots above and below the stiff slopes due to difficulties of sampling in the latter. Later, individuals were identified based on taxonomic keys provided by Gates [23] and Julka [24], counted, weighed, and preserved in the laboratory. Results were expressed in terms of biomass (fresh weight in $\mathrm{g} \mathrm{m}^{-2}$ ) and density (ind $\mathrm{m}^{-2}$ ). Using the data available, relative abundance, frequency, Simpson's index of dominance, Menhinick's species richness index, Shannon's index of general diversity, and species evenness of earthworm communities were calculated [25] and the ecological categories of earthworms [26] of the studied sites were also determined.

\subsection{Sample-Based Rarefaction Curve and Nonparametric} Richness Estimators. Sample-based data were used for the calculation of sample-based rarefaction curve, which is actually the statistical expectation of the corresponding species accumulation curve [27] to plot the cumulative number of species recorded as a function of sampling effort [28]. This curve is a classic but informal way to assess the completeness of an inventory [29]. It may provide an estimate of the total species richness of an assemblage, unless sampling has been exhaustive [30].

For the calculation of nonparametric richness estimators, sample-based data were used with ESTIMATES 8.2.0 [31] and graphs were generated by ORIGIN 6.0 Professional [32]. A total of eight richness estimators were compared based on two types of data, namely, incidence and abundance based data [33] in order to verify which fitted best the obtained data set. Estimators like Chao 1 [34], abundance based coverage estimator (ACE) [35], and first-order Jackknife richness estimators (Jackknife 1) [36, 37] are based on abundance data, whereas Chao 2 [38], incidence based coverage estimator (ICE) [35], second-order Jackknife richness estimators (Jackknife 2) [36, 37], boot strap [39], and Michaelis-Menten estimators [40] are based on incidence data. Detailed descriptions of these algorithms are available in Toti et al. [41] and Colwell [42].

2.4. Spatial Pattern Analysis. The horizontal distribution of earthworms in pineapple plantation was studied by analyzing the spatial pattern [43]. Discrete probability distributions like Poisson and Negative Binomial Distribution (NBD) models were applied to study the spatial patterns of earthworms [44]. Goodness of fit of the observed probabilities and cumulative distribution of earthworm densities were compared with the expected binomial (random distribution) and NBD (clumped 
distribution) probabilities using the Kolmogorov-Smirnov test [45-47] and Anderson Darling test [48]. Differences between relative cumulative frequencies and critical values decide whether the maximum differences between the observed and expected cumulative frequency distribution are significant [7].

Three indices of dispersion for quadrate count of earthworms were employed: the variance $\left(s^{2}\right)$ to mean $(m)$ ratio [49], Morisita's index of dispersion $\left(I_{d}\right)$ [50], and Negative Binomial (NB) parameter $(k)$ [44]. The variance to mean ratio is also called index of dispersion $(I)$. The $I$ and $I_{d}$ will give expected values $<1$ and $>1$ for uniform and clumped distribution, respectively [7]. Lower value of $k$ indicates pronounced clumping whereas its higher value indicates slight clumping. If $k$ equals zero, the clumping is maximum [44].

2.5. Soil Analysis. Soil samples were collected at $0-15 \mathrm{~cm}$ depth from the localities of maximum earthworm occurrence with a metal shovel and composite soil samples (30 samples per sampling site) comprising 5 subsamples were prepared for physicochemical analysis. Soil samples were air-dried, ground with mortar and pestle, and sieved with $1 \mathrm{~mm}$ and $2 \mathrm{~mm}$ sieves. Sieved soil samples were analyzed for their moisture (gravimetric wet weight method), $\mathrm{pH}$ (1:2.5 dilution method), soil organic matter [51], and texture [52]. Soil temperatures were recorded in situ at each sample plot at a depth of $15 \mathrm{~cm}$.

2.6. Multivariate Analysis. Pairwise comparison of earthworm species composition between three age groups of pineapple plantations was identified by calculating BrayCurtis similarity coefficient (BSC). Based on BSCs, cluster analysis was performed. A dendrogram was constructed by means of unweighted paired-group method with arithmetic averages (UPGMA) [53]. Euclidean distance (ED) was also applied in cluster analysis according to soil physicochemical properties [54]. Following cluster analysis, principal coordinates analysis (PCorA) was computed to investigate the overall variations in the present data set from different age groups of pineapple plantations and to provide an additional representation of similarity [55].

A canonical correlation analysis (CCorA) was performed to analyze the nature of relationship between soil physicochemical properties (independent variables) and overall earthworm population density and biomass (dependent variables) [56]. CCorA is a multivariate statistical model that facilitates the study of linear interrelationship between two sets of variables. One set of variables is referred to as independent variables and others are considered dependent variables; a canonical variate is formed for each set [57]. This analysis develops a canonical function that maximizes the canonical correlation coefficient between two canonical variates and determines the strength and nature of intra- and intervariable relationships [56].

Canonical correspondence analysis (CCA) [58] was performed to explore species specific associations among earthworm abundances relative to soil physicochemical parameters (temperature, moisture, $\mathrm{pH}$, and organic matter). CCA results are displayed graphically with biplot scaling focused on interspecies distances, where vectors depict environmental variables and taxa (species) are represented as points. The biplot approximates the weighted averages of each taxon (species) with respect to each of the environmental variables (soil properties).

\section{Results}

3.1. Species Composition and Community Organization. A total of 13 species of earthworms with a minimum of five and a maximum of eleven earthworm species were collected from different sampling sites of pineapple plantations. Among them, 4 species belonged to the family Megascolecidae (Metaphire houlleti (Perrier), Metaphire posthuma (Vailant), Kanchuria sp., and Kanchuria sumerianus Julka), 5 species to the family Octochaetidae (Eutyphoeus gigas Stephenson, Eutyphoeus scutarius Michaelsen, Eutyphoeus comillahnus Michaelsen, Eutyphoeus gammiei (Beddard), and Eutyphoeus sp.), 3 species to the family Moniligastridae (Drawida assamensis Gates, Drawida papillifer papillifer Stephenson, and Drawida nepalensis Michaelsen), and one species to the family Glossoscolecidae (Pontoscolex corethrurus (Muller)). In live condition, E. gammiei was the largest (length 210$320 \mathrm{~mm}$, diameter $8-12 \mathrm{~mm}$ ) earthworm and P. Corethrurus was the smallest (length $50-70 \mathrm{~mm}$, diameter $3-5 \mathrm{~mm}$ ) earthworm of pineapple plantation in Tripura (Table 1). $M$. houlleti, $M$. posthuma, and $P$. corethrurus are exotic, whereas the rest are endemic to the Indian subcontinent. Density, biomass, and relative abundance of different earthworm species are shown in Table 1 . In respect to their density, biomass, and relative abundance, $D$. assamensis was the dominant earthworm species and M. posthuma, Kanchuria sp., K. sumerianus, E. gigas, E. scutarius, E. comillahnus, E. gammiei, Eutyphoeus sp., and D. nepalensis were the rare species (Table 1) of pineapple plantations. Among 13 species, two were epianecic ( $M$. houlleti and D. papillifer papillifer), two were endoanecic (E. gigas and E gammiei), and the rest were of endogeic categories.

Density, biomass, relative abundance, and frequency of 13 earthworm species of pineapple plantations are given in Table 1. D. assamensis topped the list followed by $P$. corethrurus, D. papillifer papillifer, and M. houlleti. Density

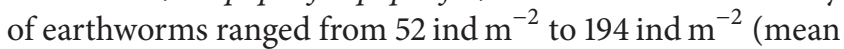
$142.3 \pm 4.43)$ and biomass ranged from $12 \mathrm{~g} \mathrm{~m}^{-2}$ to $51 \mathrm{~g} \mathrm{~m}^{-2}$ (mean $37.19 \pm 1.97$ ). Drawida assamensis was the dominant earthworm species of pineapple plantations, representing $81.2 \%$ density and $73.4 \%$ biomass of total earthworm species population. $P$. corethrurus, D. papillifer papillifer, $M$. houlleti, and Kanchuria sp. contributed $15.1 \%, 3.6 \%, 2.9 \%$, and $0.9 \%$ to total earthworm biomass.

3.2. Sampling Optimization and Nonparametric Richness Estimation. The sample-based rarefaction curve (Figure 1(a)) generated from our complete sampling revealed the observed species richness $\left(S_{\text {obs }}\right)$. Initially, the curve rose rapidly but the rate of rise slowed down later on. Thirteen earthworm species $\left(S_{\text {obs }}\right)$ were observed in the pineapple plantations of West Tripura during the present study (Table 2; Figure 1(a)). 


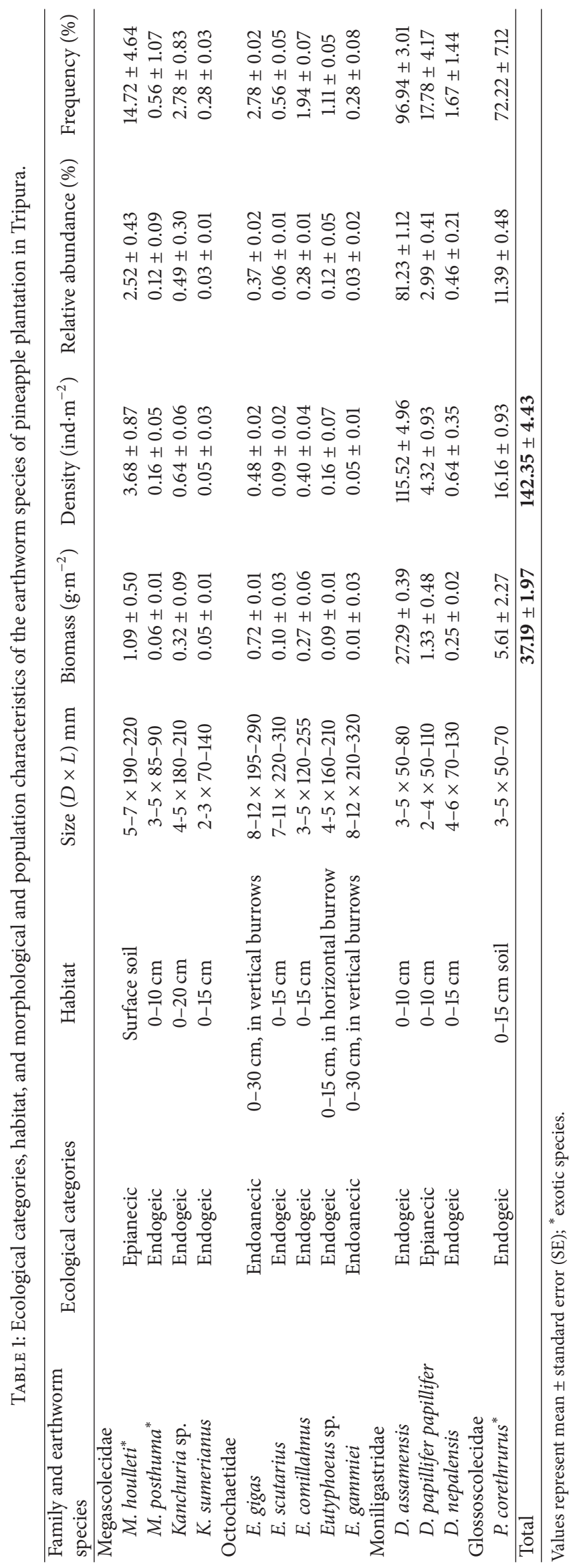




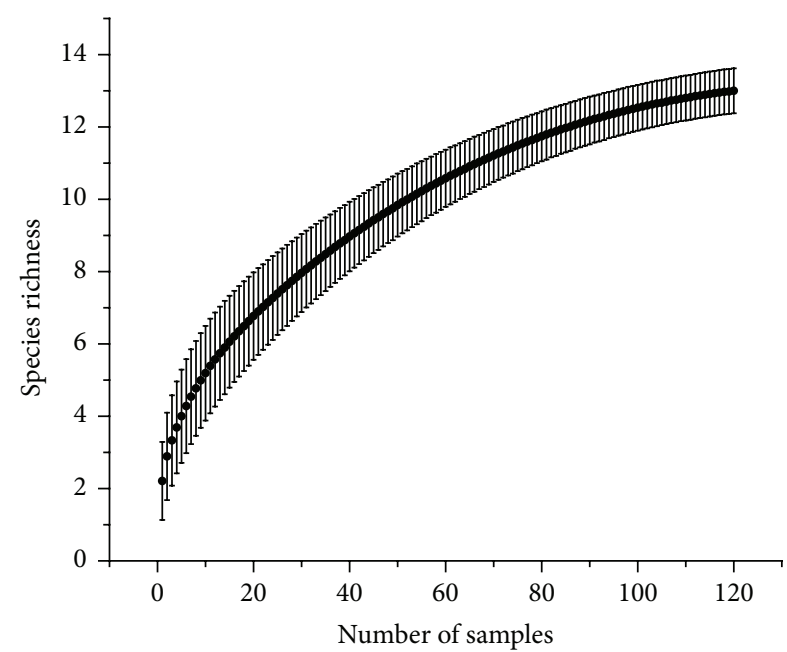

(a)

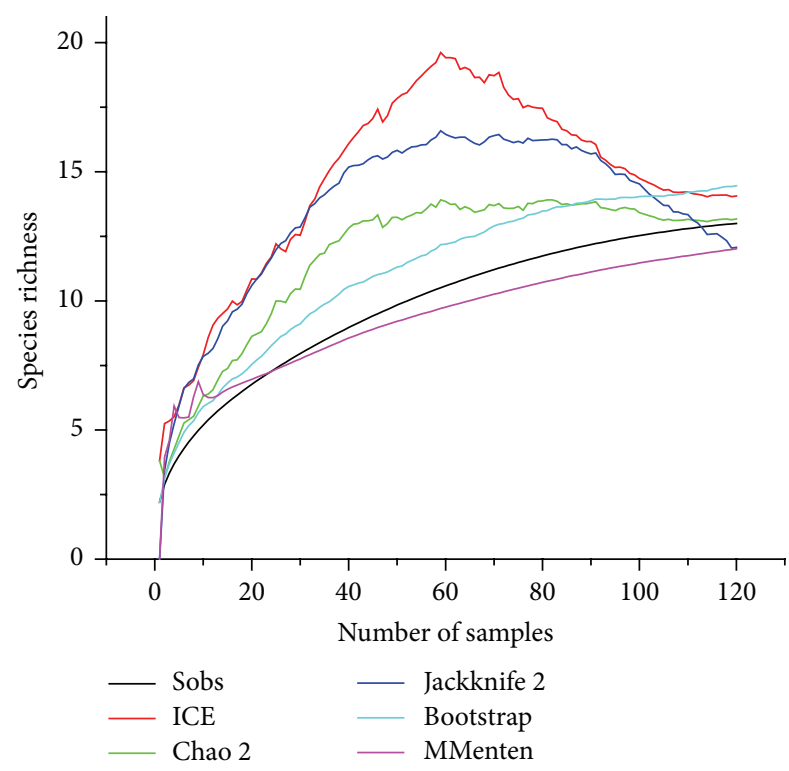

(b)

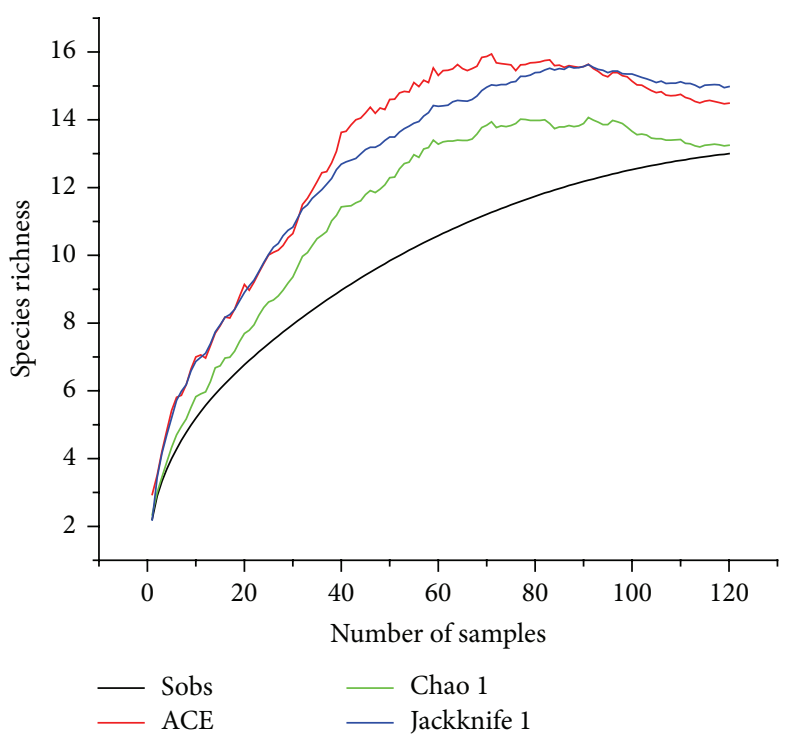

(c)

FIGURE 1: (a) Sample-based rarefaction curve revealed the observed species richness. (b) Showing the performance of incidence based nonparametric richness estimators for pineapple plantation. (c) Showing the performance of abundance based nonparametric richness estimators for pineapple plantation.

Sample-based rarefaction curve continued to rise as sample number increased and almost approached saturation while it reached up to 120 samples.

Among the richness estimators, the Jackknife 2 and Michaelis-Menten estimators underestimated the total species richness by producing the erratic and nonasymptotic curves (12.07 and 12.02) [59], whereas the Jackknife 1 and Bootstrap estimators overestimated the richness (14.98 and 14.46) [60] (Table 2; Figures 1(b) and 1(c)). The Chao 1 estimator curve closely resembled the species accumulation curve initially but leveled off in the middle and finished equally with the observed richness (Figure 1(c)). ICE and ACE curves, on the other hand, continued to rise with an increase in number of samples and appeared to fall as the number of samples approached maximum (Figures 1(b) and 1(c)). Unlike the other estimators, Chao 2 stabilized much before the total cumulative sampling effort and finished at 13 species (Figure 1(b)). This lack of consensus among the estimators is echoed in their total richness which did not cluster tightly but ranged from 12 (Michaelis-Menten) to 15 (Jackknife 1) (Table 2). Taking into consideration these curves, it appears that approximately $90-95 \%$ of species were discovered (Table 2) and another one or two earthworm species may yet be seen in the pineapple plantations of West Tripura. 


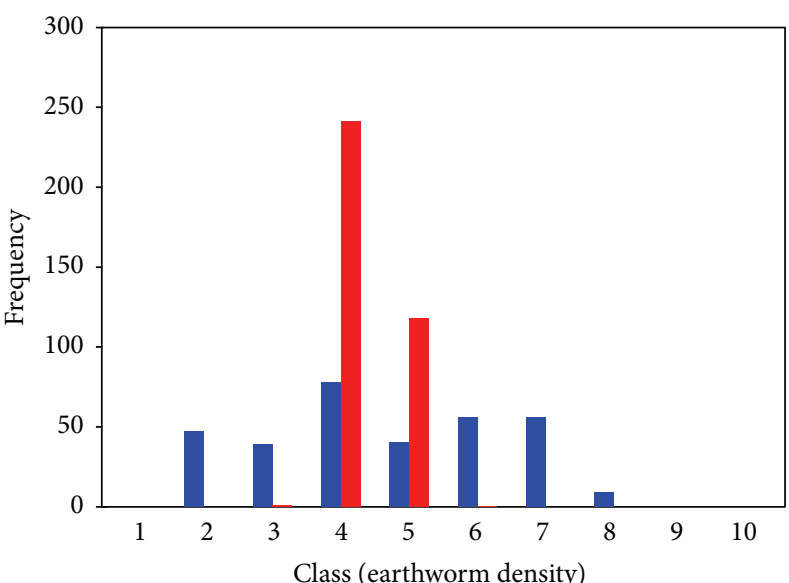

- Observations

- Distribution

(a)

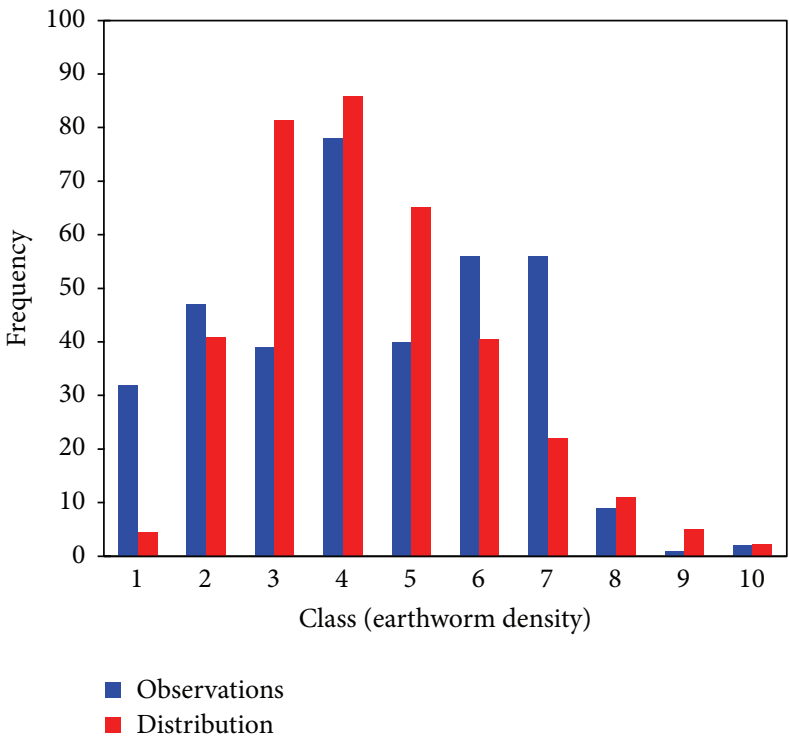

(c)

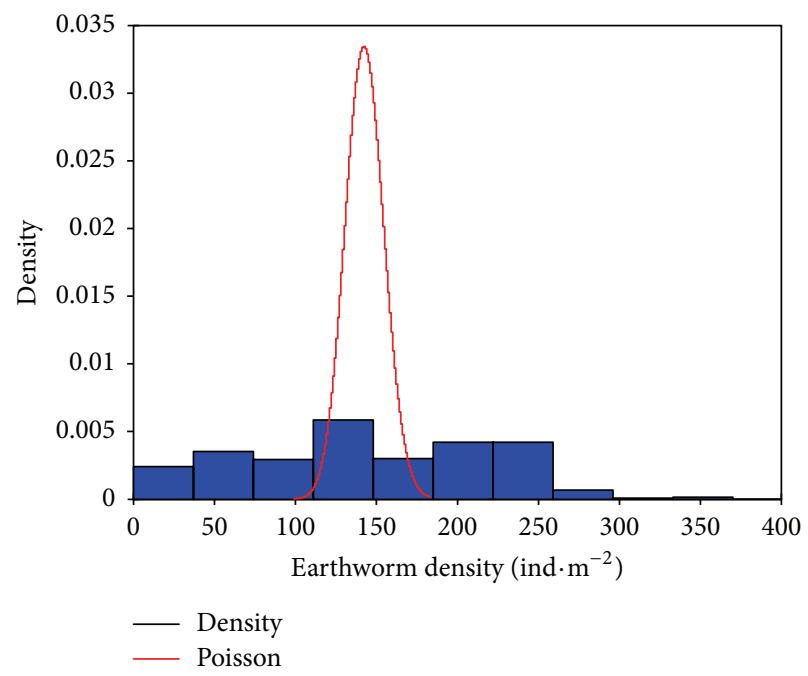

(b)

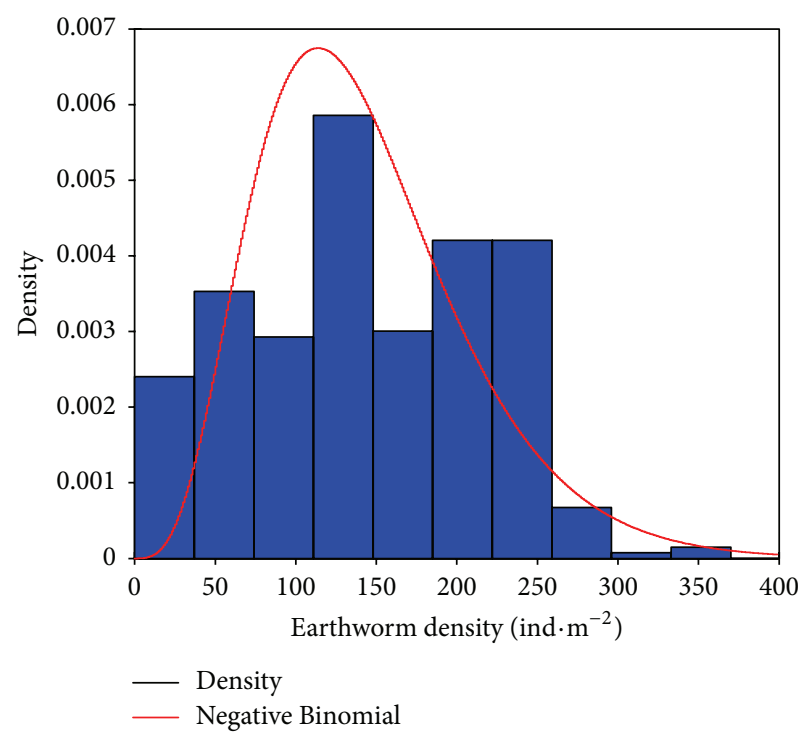

(d)

FIGURE 2: Showing the observed and expected frequency distribution and probability density function for (a, b) observed earthworm density, Poisson (random) distribution and (c, d) observed earthworm density, and Negative Binomial (clumped) distribution in pineapple plantations of Tripura.

TABle 2: Performance of different nonparametric richness estimators.

\begin{tabular}{lccc}
\hline Estimators & $\begin{array}{c}\text { Observed } \\
\text { richness }\left(S_{\text {obs }}\right)\end{array}$ & $\begin{array}{c}\text { Estimated } \\
\text { richness (Est.) }\end{array}$ & $\begin{array}{c}\text { Estimation } \\
\text { percent (\%) }\end{array}$ \\
\hline Chao 1 & 13 & 13.25 & 98 \\
ACE & 13 & 14.49 & 90 \\
Jackknife 1 & 13 & 14.98 & 87 \\
Chao 2 & 13 & 13.17 & 99 \\
ICE & 13 & 14.06 & 92 \\
Jackknife 2 & 13 & 12.07 & - \\
Michaelis-Menten & 13 & 12.02 & - \\
Bootstrap & 13 & 14.46 & 90 \\
\hline
\end{tabular}

\subsection{Spatiotemporal Patterns}

3.3.1. Horizontal Distribution. The probability density function (PDF) for observed earthworm densities and expected Poisson distribution and Negative Binomial Distribution (Figure 2) were used for detecting the spatial pattern of earthworm distribution in pineapple plantations. NBD was well fitted to the observed pattern of community when compared to Poisson distribution model. Goodness of fit of NBD rather than Poisson distribution model is the indication of spatially clumped distribution of earthworm communities in the pineapple agroecosystems.

Means of counts was 142 individuals per sampling unit for pineapple plantation. The variance counts were high and 
TABLE 3: Vertical distribution of earthworm species in different soil strata.

\begin{tabular}{lcccc}
\hline \multirow{2}{*}{ Earthworm species } & \multicolumn{5}{c}{ Depth $(\mathrm{cm})$} \\
& $0-10 \mathrm{~cm}$ & $10-20 \mathrm{~cm}$ & $20-30 \mathrm{~cm}$ & $30-40 \mathrm{~cm}$ \\
\hline M. houlleti & + & - & - & - \\
M. posthuma & + & - & - & - \\
Kanchuria sp. & + & + & - & - \\
K. sumerianus & - & + & - & - \\
E. gigas & + & + & + & + \\
E. scutarius & + & + & + & - \\
E. comillahnus & + & + & + & - \\
Eutyphoeus sp. & - & + & + & - \\
E. gammiei & - & + & + & + \\
D. assamensis & + & + & + & - \\
D. papillifer papillifer & + & + & - & - \\
D. nepalensis & + & + & + & - \\
P. corethrurus & + & + & + & - \\
\hline
\end{tabular}

(+) present; (-) absent.

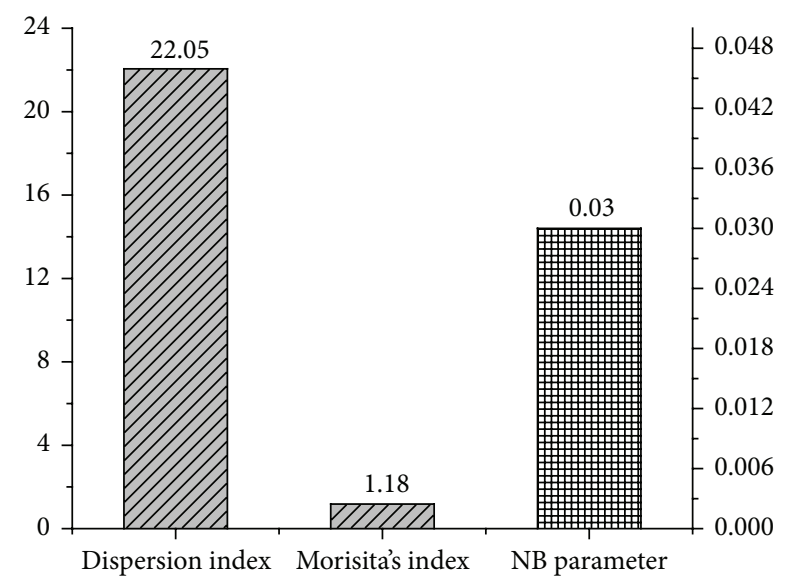

FIGURE 3: Showing the values of three different dispersion indices indicating the higher degree of clumped horizontal distribution of the earthworm community in pineapple plantation.

led to significant variance to mean aggregation (Figure 3). Morisita's index of dispersion $\left(I_{d}\right)$ was higher (1.18) and the Negative Binomial parameter $(k)$ was lower $(0.03)$ in the pineapple plantations, indicating the higher clumping spatial pattern of earthworm community in the former (Figure 3).

3.3.2. Vertical and Temporal Distribution. The assessment of vertical pattern of distribution allowed us to determine those layers that were exploited by different earthworm species. The study during the summer, monsoon, and postmonsoon period of the year 2009-2010 revealed that about $90 \%$ of the total earthworm density was concentrated in the upper $20 \mathrm{~cm}$ of soils (Figure 4), among which a clear concentration was observed in the top soils of $10 \mathrm{~cm}$ depth.

In the earthworm communities, E. gigas was found to be the most versatile species being distributed in all the vertical strata of pineapple plantation (Table 3). On the other hand, $M$. houlleti and M. posthuma were found to be restricted to the top $10 \mathrm{~cm}$ of soil (Table 3 ). By analyzing the overall vertical

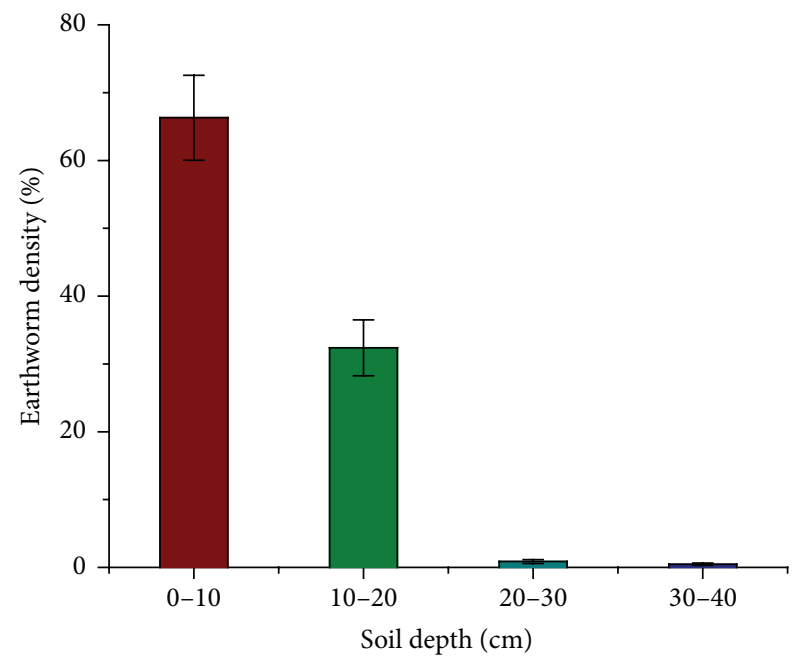

FIGURE 4: Showing concentration of earthworm density in different soil strata.

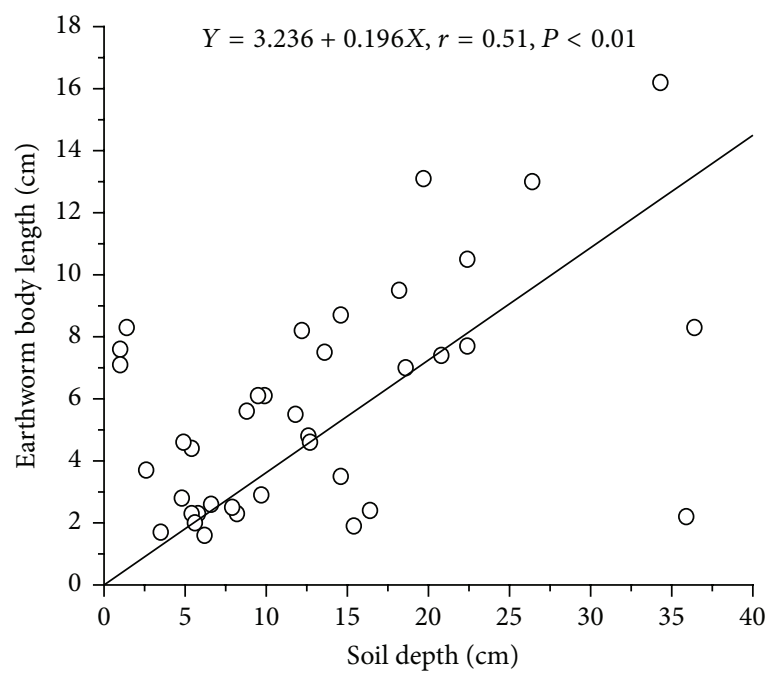

FIGURE 5: Linear regression analysis showing the overall relationship between earthworm body length and soil depth for the earthworms of pineapple plantation.

distribution data, a significant positive correlation was found between earthworm length and soil depth (Figure 5); that is, the worms having larger body length generally inhabited a greater soil depth.

In the pineapple plantations of Tripura, vertical distribution of earthworm community was influenced by seasonality. During summer (dry season), earthworm density was greater in the deeper strata $(10-20 \mathrm{~cm}, 20-30 \mathrm{~cm})$, whereas the scenario was opposite in case of wet season (rain), that is, high worm density in the top soil layer $(0-10 \mathrm{~cm}$ ) (Figure 6). A decrease in worm density during postmonsoon period, compared to monsoon in the upper strata, was noteworthy.

The overall earthworm population density and biomass were greatly influenced by seasonality in the pineapple agroecosystems of Tripura. The highest population density and biomass of earthworms were recorded during the monsoon and postmonsoon period, respectively (Figures $7(\mathrm{a})$ and $7(\mathrm{~b})$ ). 

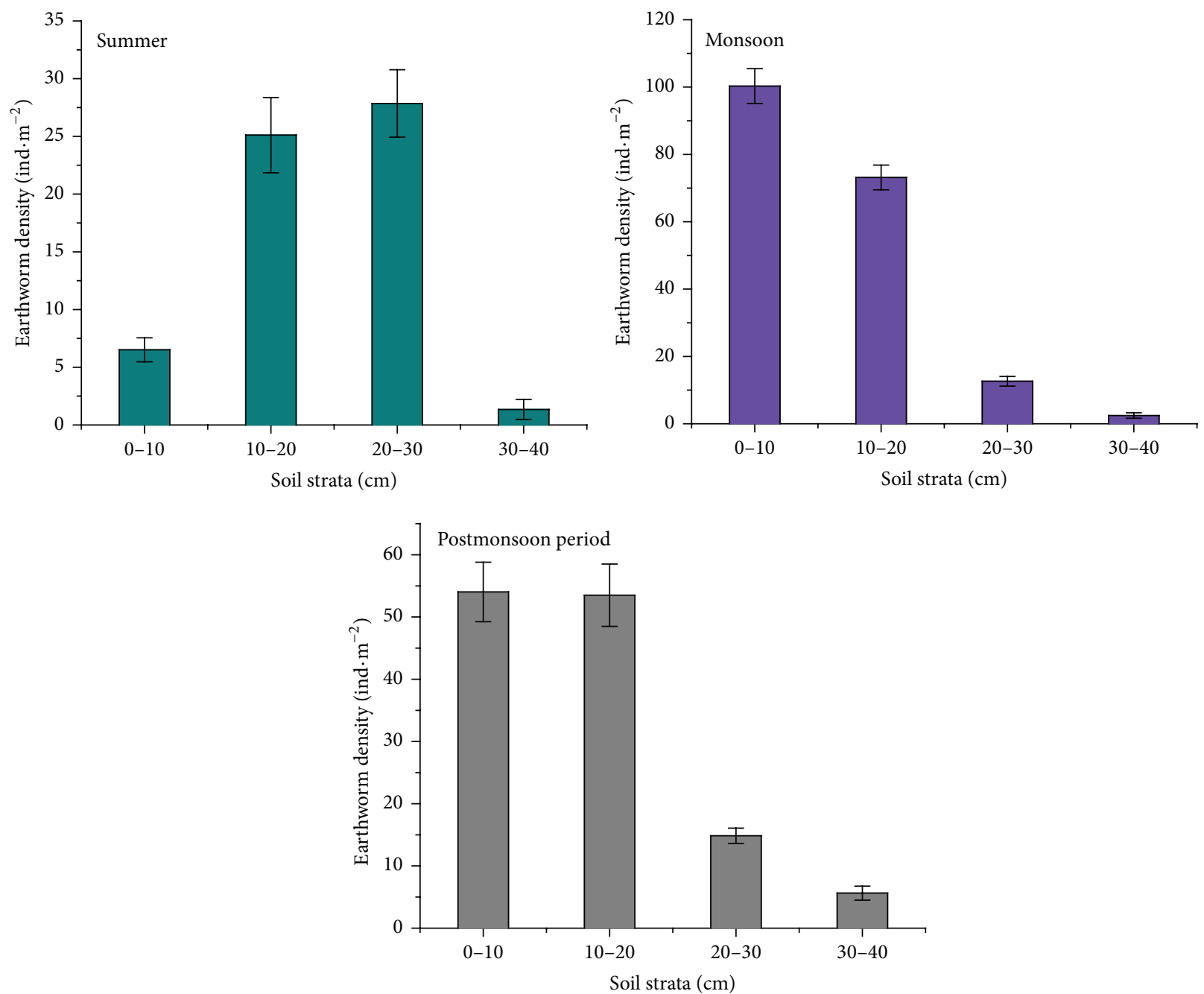

FIGURE 6: Showing the influence of seasonality on the vertical distribution of earthworm community in the pineapple plantations of Tripura.

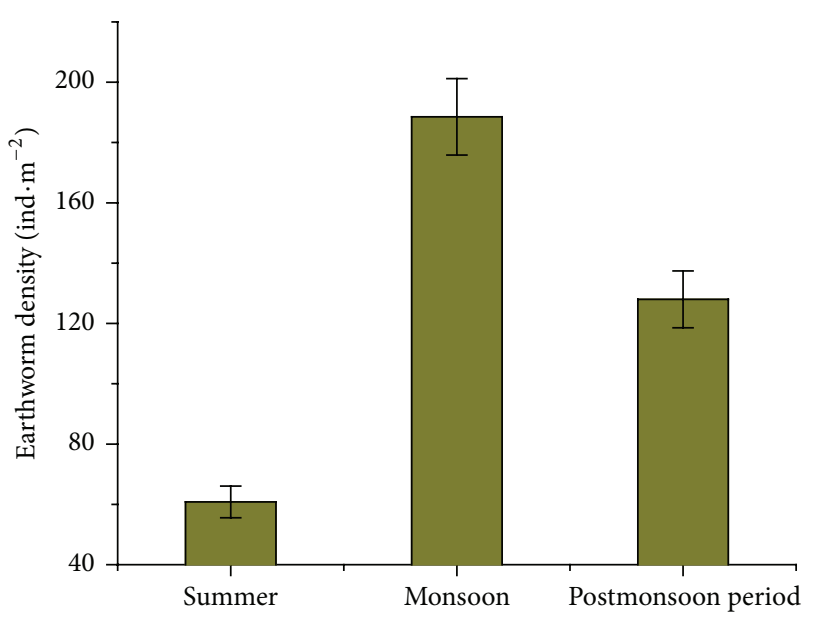

(a)

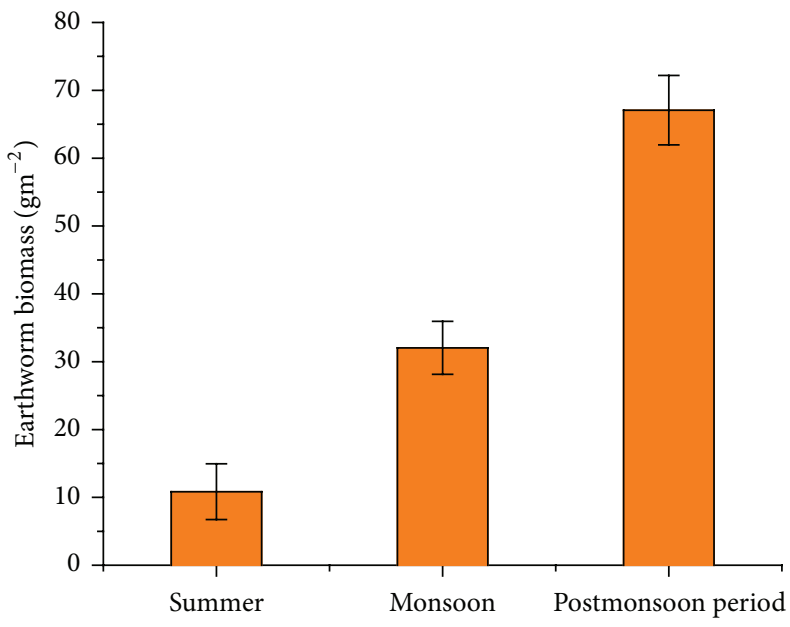

(b)

Figure 7: (a) Showing the influence of seasonality on the overall density of earthworm community in the pineapple plantation of Tripura. (b) Showing the influence of seasonality on the overall biomass of earthworm community in the pineapple plantation of Tripura. 
TABLE 4: Comparison of soil physicochemical and earthworm community parameters among different age group of pineapple plantations of Tripura.

\begin{tabular}{|c|c|c|c|}
\hline Parameters & $1-5$ years & $15-20$ years & $30-35$ years \\
\hline Soil texture & Loamy sand & Loam & Sandy loam \\
\hline Canopy cover & Absent & Minimum & Scattered \\
\hline Temperature $\left({ }^{\circ} \mathrm{C}\right)$ & $26.62 \pm 0.07^{\mathrm{a}}$ & $26.14 \pm 0.07^{\mathrm{b}}$ & $25.83 \pm 0.07^{\mathrm{c}}$ \\
\hline Moisture (\%) & $16.61 \pm 0.29^{\mathrm{a}}$ & $18.84 \pm 0.43^{\mathrm{b}}$ & $20.09 \pm 0.35^{\mathrm{c}}$ \\
\hline $\mathrm{pH}$ & $5.02 \pm 0.04^{\mathrm{a}}$ & $4.81 \pm 0.33^{\mathrm{b}}$ & $4.63 \pm 0.04^{\mathrm{c}}$ \\
\hline Organic matter (\%) & $1.36 \pm 0.02^{\mathrm{a}}$ & $1.93 \pm 0.08^{b}$ & $2.38 \pm 0.06^{\mathrm{c}}$ \\
\hline Total species richness & 07 & 07 & 11 \\
\hline Min. richness sample ${ }^{-1}$ & 1 & 1 & 1 \\
\hline Max. richness sample ${ }^{-1}$ & 3 & 4 & 5 \\
\hline \multirow[t]{6}{*}{ Mean richness sample ${ }^{-1}$} & $1.78 \pm 0.08^{\mathrm{a}}$ & $1.90 \pm 0.06^{\mathrm{a}}$ & $2.21 \pm 0.06^{\mathrm{b}}$ \\
\hline & D. assamensis & D. assamensis & D. assamensis \\
\hline & D. papillifer papillifer & D. papillifer papillifer & D. papillifer papillifer \\
\hline & E. gigas & E. gigas & E. gigas \\
\hline & M. houlleti & M. houlleti & M. houlleti \\
\hline & P. corethrurus & P. corethrurus & P. corethrurus \\
\hline \multirow[t]{6}{*}{ Species name } & M. posthuma & Kanchuria sp. & Kanchuria sp. \\
\hline & E. gammiei & Eutyphoeus sp. & Eutyphoeus sp. \\
\hline & - & - & E. scutarius \\
\hline & - & - & E. comillahnus \\
\hline & - & - & K. sumerianus \\
\hline & - & - & D. nepalensis \\
\hline Average biomass $\left(\mathrm{gm}^{-2}\right)$ & $15.04 \pm 1.83^{\mathrm{a}}$ & $23.78 \pm 2.06^{\mathrm{b}}$ & $41.92 \pm 0.67^{\mathrm{c}}$ \\
\hline Average density $\left(\right.$ ind $\cdot \mathrm{m}^{-2}$ ) & $53.73 \pm 2.57^{\mathrm{a}}$ & $77.20 \pm 2.89^{\mathrm{b}}$ & $158.67 \pm 8.17^{\mathrm{c}}$ \\
\hline
\end{tabular}

Values represent mean \pm standard error (SE); dissimilar letters indicate significant difference at $5 \%$ level of significance.

Interestingly, while earthworm biomass increased gradually with the seasonality from summer to postmonsoon period, earthworm density showed a sudden increase followed by a considerable decrease (Figures 7(a) and 7(b)).

\subsection{Impact of Pineapple Plantation Age on Earthworm Com-} munity. Comparative studies on structure of earthworm communities in the three age groups of pineapple plantations (1-5 years, 15-20 years, and 30-35 years) revealed common occurrence of at least 5 species (Drawida assamensis, Drawida papillifer papillifer, Eutyphoeus gigas, Metaphire houlleti, and Pontoscolex corethrurus) of earthworms (Table 4). Species richness was significantly $(P<0.05)$ higher in the 3035 -year-old plantation with eleven species (mean species richness $2.21 \pm 0.06$ ), while in the other age groups of plantations it was only seven (mean species richness: $1.9 \pm$ 0.06 (15-20 yrs); $1.8 \pm 0.08$ (1-5 yrs)).

Cluster analysis based on Euclidean distance and BrayCurtis similarity coefficient revealed the distance and similarity between the three plantation types in terms of soil properties and earthworm species composition. Both dendrograms divide all the studied sites into two distinct categories (immature and old) based on plantation age (Figure 8(a)). The cluster of immature plantations again was subdivided into two definite age groups (juvenile and young). Immature and old plantation groups showed least similarity and highest distance (BSC 0.55 and ED 95). On the other hand, juvenile and young plantations showed BSC 0.72 and ED 25. This clustering almost perfectly classified pineapple plantation based on age structure.

Results of UPGMA clustering based on Bray-Curtis index were confirmed by the pattern of PCorA plotting (Figure $8(\mathrm{~b})$ ). A total of $94 \%$ of the variations among different age group of pineapple plantations was explained by the first two principal coordinates accounting for $84.2 \%$ and $9.9 \%$ of total variance, respectively. The first principal coordinate clearly divided studied sites into three groups, forming three clusters based on plantation age. This pattern corresponded entirely with the clusters of UPGMA dendrogram.

Interestingly, there was an increasing trend in the overall biomass and density of earthworms with increase in the plantation age. Maximum earthworm density $\left(158\right.$ ind $\mathrm{m}^{-2}$ ) and biomass $\left(42 \mathrm{~g} \mathrm{~m}^{-2}\right)$ were recorded in 30-35-year-old pineapple plantation. Earthworm population density and biomass differed significantly $(P<0.05)$ among different age groups of plantations (Table 4$)$.

A significant decrease $(P<0.05)$ in Shannon diversity index and species evenness and increase $(P<0.05)$ in Simpson's dominance index with increase in the age of pineapple plantations was noted (Figure 9). Morisita's index of dispersion $\left(I_{d}\right)$ was greater than 1 in all the age groups of pineapple plantations that revealed aggregated nature of 


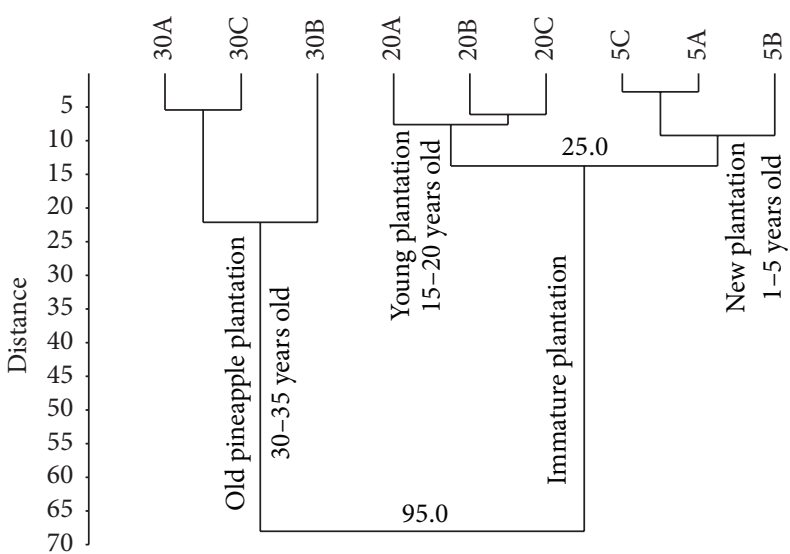

(A)

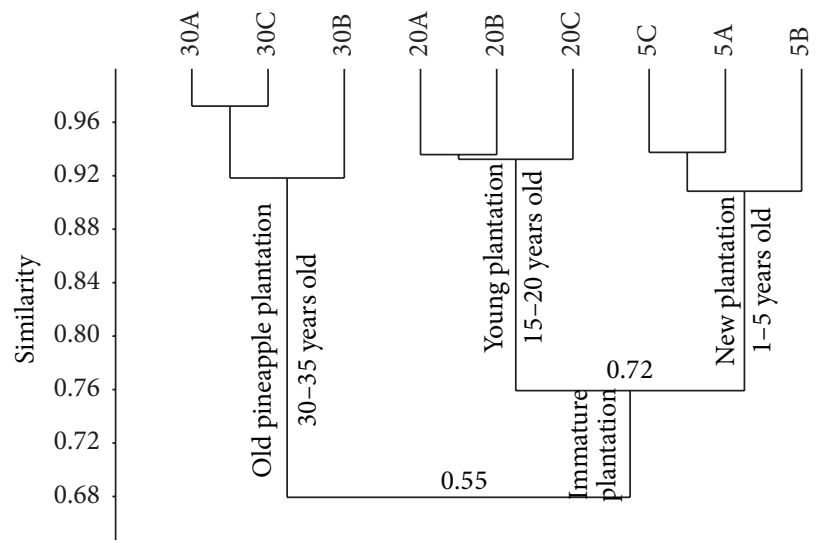

(B)

(a)

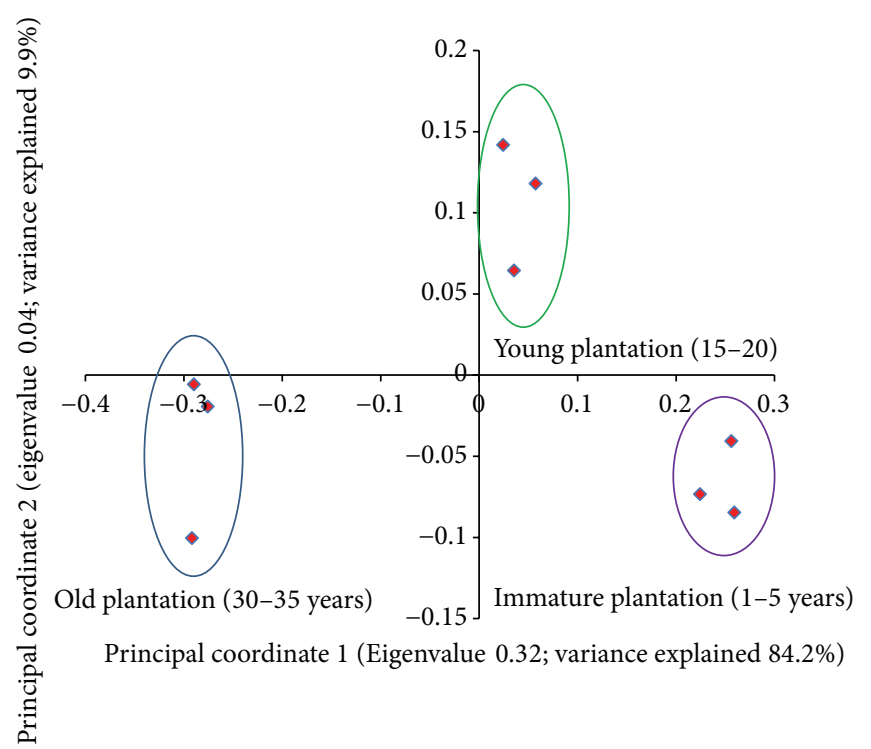

(b)

Figure 8: (a) Clustering of sampling plots: (A) according to soil properties (Euclidean distances); (B) according to characteristics of earthworm assemblages and species composition (Bray-Curtis index). (b) Principal coordinates analysis of pineapple plantation sampling plots. First and second principal coordinates explain $81.9 \%$ and $11.9 \%$ of total variance, respectively.

spatial distribution of earthworm communities (Figure 9). Highest value (1.28) of $I_{d}$ in 15-20-year age group of plantation indicated the highest degree of clumping.

\subsection{Analysis of Relationship between Soil Properties and Earth-} worms. Distribution of earthworm species in the pineapple agroecosystems with reference to their ecological parameters, namely, temperature, moisture, $\mathrm{pH}$, and organic matter, is given in Table 5. Earthworms experienced a mean soil temperature of $25.8^{\circ} \mathrm{C}$, moisture of $20.4 \%, \mathrm{pH}$ of 4.6 , and organic matter of $2.3 \%$ in the pineapple plantations of Tripura. In the studied sites, D. assamensis, D. papillifer papillifer, P. corethrurus, M. houlleti, and E. gigas had wide range and E. comillahnus, Kanchuria sp., K. sumerianus, and $D$. nepalensis showed narrow range of tolerance to edaphic factors (Table 5).
CCorA indicated that only a single relationship exists between the soil properties (independent variables) and the earthworm population characters (dependent variables) which is supported by a lack of statistical significance $(P>$ 0.05 ) in the second canonical function (Table 6). Therefore, only the first canonical function $(P<0.01)$ explaining $75 \%$ of the total variance can be considered for drawing an inference on relationship between two variables. In this study, interpretation based on canonical weights is not considered due to lack of noncollinearity among the independent variables. Based on canonical and squared canonical loadings, soil temperature $(0.96,0.93)$ and $\mathrm{pH}(0.91,0.83)$ were identified as most important independent variables followed by soil organic matter and moisture (Table 6 ). In studying cross- and squared cross-loadings for the first canonical function, soil temperature was found to be the most potent 
TABLE 5: Occurrence of different earthworm species of pineapple plantation in different ecological conditions in Tripura.

\begin{tabular}{|c|c|c|c|c|}
\hline Family and earthworm species & Temperature $\left({ }^{\circ} \mathrm{C}\right)$ & Moisture (\%) & Soil pH & Organic matter (\%) \\
\hline \multicolumn{5}{|l|}{ Megascolecidae } \\
\hline M. houlleti & $26.2 \pm 0.28$ & $19.78 \pm 1.02$ & $4.64 \pm 0.10$ & $2.03 \pm 0.22$ \\
\hline M. posthuma & $24.8 \pm 0.75$ & $20.50 \pm 1.43$ & $5.72 \pm 0.07$ & $3.84 \pm 0.06$ \\
\hline Kanchuria sp. & $26.2 \pm 0.30$ & $19.39 \pm 0.85$ & $4.63 \pm 0.10$ & $2.11 \pm 0.17$ \\
\hline K. sumerianus & $26.8 \pm 0.11$ & $19.21 \pm 0.75$ & $4.79 \pm 0.06$ & $2.24 \pm 0.05$ \\
\hline \multicolumn{5}{|l|}{ Octochaetidae } \\
\hline E. gigas & $26.1 \pm 0.58$ & $20.35 \pm 0.78$ & $4.51 \pm 0.15$ & $2.00 \pm 0.20$ \\
\hline E. scutarius & $25.9 \pm 1.25$ & $22.53 \pm 2.14$ & $5.23 \pm 0.68$ & $3.14 \pm 0.88$ \\
\hline E. comillahnus & $27.0 \pm 0.35$ & $19.96 \pm 0.42$ & $4.81 \pm 0.09$ & $2.72 \pm 0.19$ \\
\hline Eutyphoeus sp. & $25.3 \pm 1.05$ & $19.12 \pm 0.97$ & $5.02 \pm 0.22$ & $1.61 \pm 0.16$ \\
\hline E. gammiei & $25.0 \pm 0.40$ & $23.29 \pm 0.89$ & $5.76 \pm 0.13$ & $2.33 \pm 0.14$ \\
\hline \multicolumn{5}{|l|}{ Moniligastridae } \\
\hline D. assamensis & $25.5 \pm 0.31$ & $19.03 \pm 0.89$ & $4.59 \pm 0.14$ & $2.16 \pm 0.30$ \\
\hline D. papillifer papillifer & $25.4 \pm 0.32$ & $19.67 \pm 1.27$ & $4.67 \pm 0.15$ & $1.97 \pm 0.21$ \\
\hline D. nepalensis & $26.3 \pm 0.12$ & $20.69 \pm 0.18$ & $4.41 \pm 0.21$ & $2.38 \pm 0.10$ \\
\hline \multicolumn{5}{|l|}{ Glossoscolecidae } \\
\hline P. corethrurus & $25.7 \pm 0.70$ & $18.38 \pm 1.08$ & $4.77 \pm 0.18$ & $2.16 \pm 0.28$ \\
\hline
\end{tabular}

Values represent mean \pm standard deviation (SD).

TABLE 6: Summary result of canonical correlation analysis relating soil properties and earthworm population characteristics.

(a) Measures of overall model fit for canonical correlation analysis

\begin{tabular}{lcccc}
\hline Canonical function & Canonical correlation & Eigen value & $\chi^{2}$ & $P$ value \\
\hline 1 & 0.87 & 0.75 & 42.9 & 0.00 \\
2 & 0.49 & 0.25 & 7.25 & 0.06 \\
\hline
\end{tabular}

(b) Canonical weights, loadings, squared loadings, cross-loadings, squared cross-loadings, and redundancy index for the first canonical function

\begin{tabular}{|c|c|c|c|c|c|c|}
\hline Variables & $\begin{array}{c}\text { Canonical } \\
\text { weight }\end{array}$ & $\begin{array}{l}\text { Canonical } \\
\text { loading }\end{array}$ & $\begin{array}{c}\text { Squared } \\
\text { canonical loading }\end{array}$ & $\begin{array}{c}\text { Canonical } \\
\text { cross-loading }\end{array}$ & $\begin{array}{l}\text { Squared canonical } \\
\text { cross-loading }\end{array}$ & $\begin{array}{c}\text { Redundancy } \\
\text { index }\end{array}$ \\
\hline \multicolumn{7}{|l|}{ (A) Independent } \\
\hline (1) Temperature & 1.98 & 0.96 & 0.93 & -0.84 & 0.70 & \multirow{4}{*}{0.62} \\
\hline (2) Moisture & 1.01 & -0.87 & 0.76 & 0.76 & 0.57 & \\
\hline (3) Organic matter & -0.27 & -0.87 & 0.76 & 0.76 & 0.57 & \\
\hline (4) Soil pH & -0.28 & 0.91 & 0.83 & -0.79 & 0.63 & \\
\hline \multicolumn{7}{|l|}{ (B) Dependent } \\
\hline (1) Worm density & 0.85 & 0.83 & 0.69 & -0.72 & 0.52 & \multirow{2}{*}{0.36} \\
\hline (2) Worm biomass & 0.56 & 0.52 & 0.27 & -0.45 & 0.21 & \\
\hline
\end{tabular}

predictor of dependent variables with negative correlation explaining $70 \%$ variance of function 1 , followed by soil pH (63\%). Among dependent variables, earthworm density (cross-loading: -0.72) was mostly affected by independent variables compared to biomass explaining $52 \%$ and $21 \%$ of the variance, respectively (Table 6). Independent variables with high redundancy index $(0.62)$ confirm their ability in predicting the values of dependent factors, namely, earthworm density and biomass.
According to CCA ordination, common earthworm species of pineapple plantation with greater relative abundance, namely, D. assamensis, P. corethrurus, D. papillifer papillifer, and M. houlleti, were mainly regulated by studied soil physicochemical properties (temperature, moisture, $\mathrm{pH}$, and organic matter) (Figure 10). The dominant species, D. assamensis, was strictly associated with acidic $\mathrm{pH}$, low temperature, and high moisture, whereas others preferred comparatively higher $\mathrm{pH}$ and temperature. Distribution of 


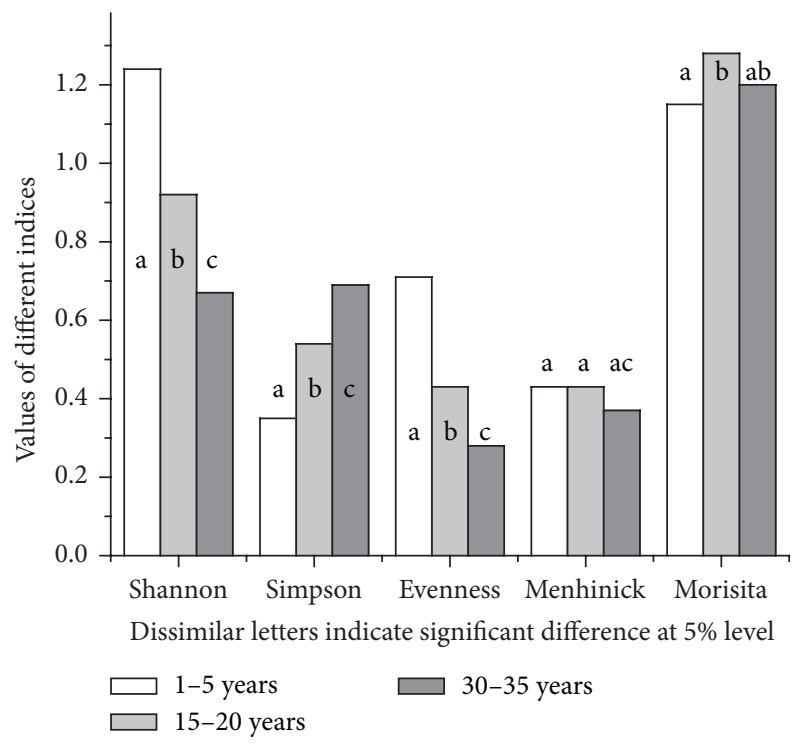

FIGURE 9: Showing the variation among diversity and dispersion indices in the three age groups of pineapple plantation.

most of the rare earthworm species was controlled by several unstudied factor combinations. However, E. comillahnus chiefly associated with greater organic matter and moisture content (Figure 10).

\section{Discussion}

The present study recorded 13 species of earthworms from the pineapple plantations of Tripura representing 5 genera and 4 families. Among the 13 species of earthworms, 3 species, namely, $M$. houlleti, $M$. posthuma, and P. corethrurus, are exotics and the rest are either native or endemic. Occurrence of a greater number of endemic species in the soils of pineapple plantations of Tripura indicates that the region belongs to biodiversity hot spot zone where the native species coexist with the exotics. This is in contrast to tropical countries like Peru, Brazil, and Mexico where native species of earthworms have largely been replaced by exotics [61, 62]. Kanchuria sp. and Eutyphoeus sp. are new species (yet to be described) of Tripura. Interestingly, Eutyphoeus comillahnus shows restricted distribution only in Tripura of India [63]. Eleven (M. houlleti, Kanchuria sp., K. sumerianus, E. gigas, E. scutarius, E. comillahnus, E. gammiei, D. assamensis, D. papillifer papillifer, D. nepalensis, and P. corethrurus) and five (E. gigas, E. comillahnus, E. gammiei, D. nepalensis, and $P$. corethrurus) species in the pineapple plantations of Tripura had also been reported from the soils of other habitats including rubber plantations in Tripura [64, 65] and its neighboring country Bangladesh [66]. At least eight earthworm species of pineapple plantations ( $M$. houlleti, $M$. posthuma, K. sumerianus, E. gammiei, D. assamensis, D. papillifer papillifer, D. nepalensis, and P. corethrurus) had previously been reported from other northeastern states of India [18, 67, 68]. Recently, Lalthanzara and Ramanujam
$[69,70]$ reported the presence of $M$. houlleti, Drawida sp., Perionyx excavatus, Perionyx macintoshi, and Eutyphoeus mizoramensis in the agroforestry system of Mizoram.

A minimum of five and maximum of eleven earthworm species distributed in the studied pineapple plantations corroborated the reported range of 4-14 species in the earthworm communities of tropical rain forest [11]. Occurrence of only 5 earthworm species in the pineapple plantations of East Khasi Hills in Meghalaya was reported by Tiwari et al. [18]. Such less species richness of earthworms was probably linked with altitude effect on faunal diversity [71, 72]. In fact, less number of earthworm species at higher altitude has been attributed to low temperature and unfavorable edaphic factors $[73,74]$. Although pineapple plantation is a monoculture, its earthworm diversity is not remarkably less in comparison to the mixed fruit plantations of Tripura $[75,76]$. This is due to the fact that mostly fallow lands were converted to pineapple plantations in order to check soil degradation, so that the original earthworm communities were retained $[76,77]$. In addition, varieties of weeds, herbs, and shrubs found over the floors of the studied pineapple plantations under the tropical conditions with heavy rainfall in Tripura provide suitable physical habitat and trophic resource for a diverse earthworm community [75]. Dense arrangement of pineapple plants in the mature plantations that curtail solar radiation, protect surface soil from the thrust of rain, and reduce air temperature allows moisture conservation and retains soil organic carbon which creates favorable microclimatic conditions for the soil dwelling earthworms [78].

Drawida assamensis is the dominant species with respect to its biomass, density, relative abundance, and frequency in pineapple plantations. Interestingly Tiwari et al. [18] also reported $D$. assamensis as the dominant earthworm species in the pineapple plantations of East Khasi hills in Meghalaya. Dominance of $D$. assamensis in the studied plantations may be linked with "individual plant species effect" that favored $D$. assamensis over other species of earthworms [79]. Earthworm communities of monoculture agroecosystems dominated by single earthworm species were reported earlier by Chaudhuri and Nath [5] and Dey et al. [80]. Dominance of exotic earthworm Pontoscolex corethrurus in the rubber plantations of Tripura was reported by Nath [65]. Earthworm density and biomass (contributed mainly by Drawida assamensis) in pineapple plantation is comparable to other monoculture plantations like acacia, rubber $[12,81]$, and pine forests $[4,82]$, respectively.

Although sample-based rarefaction curve does not provide an estimation of asymptotic species richness [83], this can be used to evaluate sampling adequacy by assessing whether the cumulative number of species reaches a plateau and to compare observed species richness with nonparametric estimators [28]. In the pineapple plantation, inventory was not complete as revealed by the sample-based rarefaction curve $[84,85]$ after a reasonably large sampling effort, thus revealing that additional sampling effort would be needed to assess the true diversity of the earthworms in the study area. Less heterogeneous habitat conditions due to monoculture nature of plantation, dominance of $D$. assamensis in the assemblage, and patchy distribution of earthworms in 


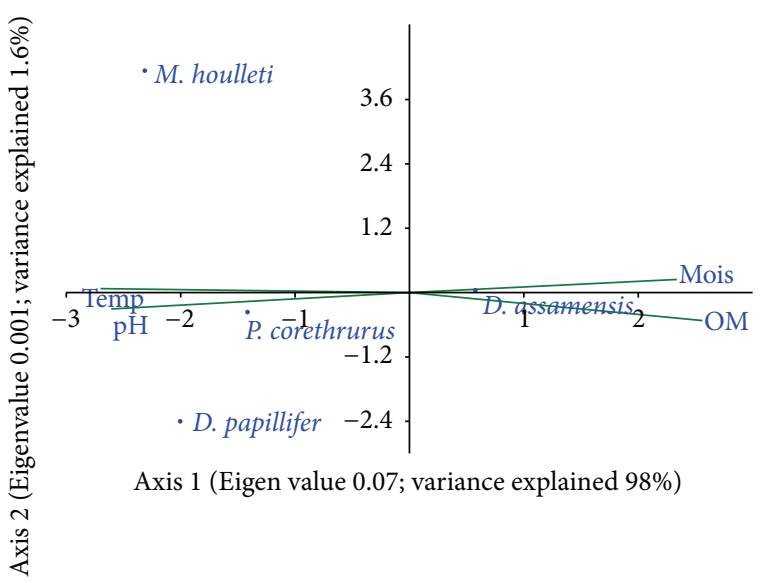

(a)

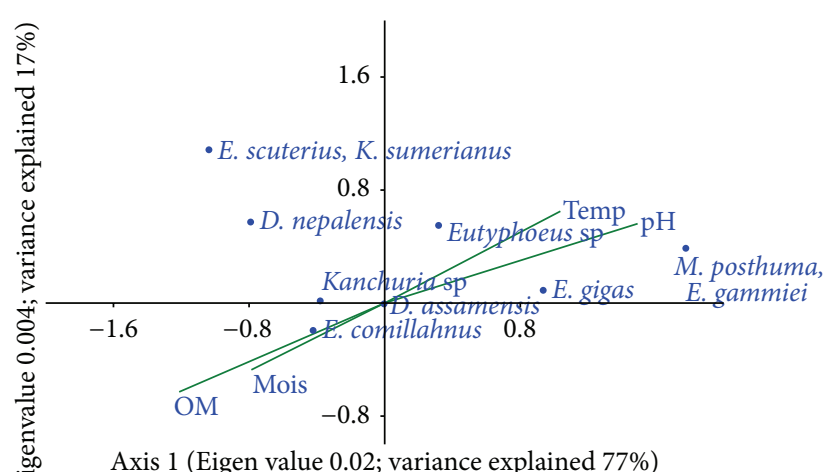

(b)

FIGURE 10: Canonical correspondence analysis (CCA) indicated the relationship between soil physicochemical parameters and (a) common and (b) rare earthworm species of pineapple plantation.

the pineapple plantations of Tripura are the possible factors for nonattainment of asymptotic species richness [86-88].

Among the selected eight nonparametric estimators, except for Jackknife 2 and Michaelis-Menten, others converged closely on the observed species richness. Since each estimator has been developed to work under the assumptions defined by a specific population model [89], performance tests must be carried out for the richness estimators for each case of inventory. In this case, Chao 2 estimator can be considered best suited for the present data set since it reached a stable asymptote earlier than the sample-based rarefaction curve [41] and the asymptote (13 species) was reached approximately after $83 \%$ of total sampling effort, the value of which was higher than other estimators [90]. Comparable results were obtained in other studies on both macro- and microorganisms with unequal catchability [21, 91, 92]. A great advantage of Chao 2 richness estimator is that it relies not on the precise abundance values of individuals and number of singletons and doubletons but on uniques and duplicates [60].

Earthworms are organisms with a highly contagious spatial distribution [93]. The present study agrees with Sileshi [44] and Chaudhuri and Dey [75] who found that earthworms were highly aggregated in the agroforestry assemblages of Eastern Zambia and West Tripura (India), respectively. According to Lloyd [94], aggregation indices are higher for rare species and M. posthuma, Kanchuria sp., K sumerianus, D. nepalensis, and members of the genus Eutyphoeus are the rare species of pineapple plantations [84]. Highly clustered horizontal distribution of earthworm communities in the pineapple plantations of West Tripura, dominated by the small sized endogeic earthworm D. assamensis $[75,76]$, corroborates the studies of Rossi and Lavelle [93] and Jiménez et al. [95], who also reported a negative correlation between earthworm size and horizontal distribution in case of earthworm communities from savannas of Africa and Columbia, respectively. Individual plant distribution as well as root architecture and activity [96] along with microtopography or intrinsic population processes like dispersal, reproduction, or competition [97] may also influence the spatial distribution of earthworms in the pineapple plantations.

Generally the replacement of original ecosystems by different land use systems of human origin has a deep impact on the functioning of the ecosystems [98]. The lack of clear relationship between the biometric variables employed, namely, length-diameter $(L / D)$ and weight-diameter $(W / D)$ ratios, and the vertical distribution of earthworm species studied was in line with other studies [99-101] in which larger species were found to be distributed deep in the soil profile. Lalthanzara and Ramanujam [70] and Piearce [102] also reported a positive correlation between earthworm size and depth of burrow. Higher density of earthworms in the upper soil strata $(0-10 \mathrm{~cm})$ of pineapple plantations corroborates Lalthanzara and Ramanujam [70], Kaushal et al. [103] and Bisht et al. [104], which may be attributed to higher percentage of organic matter, moisture, and availability of food. A gradual decrease in soil macroinvertebrate population with increase in soil depth was also recorded by Doblas-Miranda et al. [105] with small differences between microhabitat. Less density of earthworms in the deeper soil stratum during the activity period reveals the fact that the deeper stratum is not suitable for the majority of the species recorded.

Soil temperature and rainfall are the most potent regulatory factors for vertical distribution of earthworms [106]. Lower earthworm density in the upper stratum $(0-10 \mathrm{~cm})$ of soils during summer compared to $10-20 \mathrm{~cm}$ depth might be linked with lower soil moisture content and downward migration of earthworm to avoid extreme conditions [107]. Since the environmental conditions of tropical soil ecosystems are highly influenced by strong seasonality, earthworms migrate deeply to aestivate in different ways [99, 101]. The soil depth and physical characteristics of the soils are the most important factors influencing differential distribution 
of earthworm population exposed to seasonal variations [3, 106].

Unlike summer and postmonsoon period, a greater population density during monsoon in the pineapple plantations is probably related to higher breeding rate of earthworms at that period [11]. According to Chaudhuri and Bhattacharjee [108], D. assamensis is a discrete breeder and reproduces mainly during monsoon. However, earthworms in general favor monsoon for reproduction mainly due to favorable temperature that acts as cue for increased neurosecretion favoring cocoon production [109]. Lower density of earthworms with greater biomass during postmonsoon period is mainly attributed to higher monsoon mortality rate of juveniles compared to young and adults; these grow well in presence of suitable growth parameters like temperature, organic matter, and so forth $[99,110]$.

A minimum of seven (1-5-year-old and 15-20-yearold plantation) and a maximum of eleven (30-35-year-old plantation) earthworm species were distributed in the studied sites among the 13 earthworm species found during our survey. The difference in the species composition in the earthworm communities among the different studied age groups of pineapple plantations of West Tripura indicates the importance of habitat heterogeneity ( $\beta$-diversity) in the diversity of earthworms as shown by Fragoso and Lavelle [111] in the forests of Mexico.

A gradual increase in average biomass and density of earthworms with plantation age is also reported in case of several other monocultures like rubber and Eucalyptus [112-114]. An approximate fourfold increase in density and threefold increase in biomass of earthworms in the 3035 -year age group plantation compared with the 1-5-yearold plantation were probably due to a significant increase $(P<0.01)$ in soil organic carbon and soil moisture and significant decrease $(P<0.01)$ in temperature with increasing plantation age [11]. Decaëns et al. [115] proposed that increased faunal activity with the aging of plots was due to availability of trophic resource (i.e., dead roots and decomposed leaves) that sustained a high carrying capacity.

The gradual decrease in the indices of Shannon diversity together with an increase in dominance is probably linked with the dramatic increase in the population density of dominant earthworm $D$. assamensis in pineapple plantations with increase in their age. According to Shakir and Dindal [116], population density is negatively correlated with species diversity. The lower population densities for the rare species were linked to high diversity, and the highest population densities for dominant species correlated with lower diversity. Thus, lower population densities of rare octochaetid species such as E. gigas, E. comillahnus, and E. scutarius in young plantations (1-5 year old) and higher population densities of dominant earthworm species, D. assamensis, in aged plantation (30-35 years old) were correlated with higher diversity in the former and lower diversity in the latter.

Highest value of Morisita's index $\left(I_{d}\right)$ in 15-20-year plantation may be due to greater heterogeneity in soil conditions and food distribution [117] than in other plantation groups. A gradual decrease in the soil environmental heterogeneity [118] coupled with decline in the intensity of disturbance [95] with increasing plantation age may contribute to the decrease in Morisita's index $\left(I_{d}\right)$, that is, less clumped earthworm community with increase in the pineapple plantation age.

A number of ecological factors are known to play a vital role in the distribution, diversity, and abundance of earthworms [11]. Earthworm species in pineapple plantation occurred in moist (20\% moisture) and acidic soils ( $\mathrm{pH} \mathrm{4.6)}$ with temperature $26^{\circ} \mathrm{C}$ and organic matter $2.3 \%$. Because of their narrow ecological plasticity to soil edaphic factors, members of the largest native genus Eutyphoeus [119] can be considered as "stenoecious." On the other hand, exotic peregrine worms like $M$. houlleti, M. posthuma, and $P$. corethrurus and native peregrine species like $D$. nepalensis, $D$. papillifer papillifer, and so forth with wide ecological plasticity are called "euryoecious".

Soil temperature and moisture are usually inversely related and act synergistically to influence earthworm activity by affecting their metabolism, respiration, growth, reproduction, and osmoregulation [120]. In the present study, soil temperature and moisture had a significantly strong negative and positive correlation with the density and biomass of earthworms, respectively. Such correlations were also reported by several other workers from different natural and artificial agroecosystems across the tropics [18, 65, 77, 85]. According to Edwards and Bohlen [11], earthworm densities and biomasses are negatively affected by temperature due its inverse relationship with soil moisture content. However, optimum temperature increases biodiversity by improving access to soil nutrients and organic resources [121].

Earthworms are very sensitive to soil $\mathrm{pH}$ that limits their density and distribution [11]. Significant negative correlation between soil $\mathrm{pH}$ and overall earthworm density and biomass in the present study results from the domination of acidophilic ( $D$. assamensis) and other acid-tolerant earthworm species in the pineapple plantations of Tripura [84]. Recently, Bhattacharjee [77] reported negative correlation between soil $\mathrm{pH}$ and earthworm population in rubber plantation. Spiers et al. [122] reported acid-tolerant earthworm species, Arctiostrotus sp., in the organic soil with $\mathrm{pH}$ ranging from 2.6 to 6.2 in the coniferous podzols of Vancouver Island, Canada. Earlier, Bachelier [123] reported that certain tropical species of Megascolex thrived in the acid soils with $\mathrm{pH}$ of 4.5 to 4.7. It has been advocated that acidophilic species of earthworm have a major role in the decomposer subsystem of soil ecosystem [11]. Staaf [124] suggested that $\mathrm{pH}$ and factors related to $\mathrm{pH}$ had very important influence on the distribution and abundance of earthworms in the acid beech forest soils in Sweden.

Organic matter has an important influence on earthworm population, activities, and their enzyme activities [125]. Significantly positive correlation $(P<0.05)$ between earthworm population density and soil organic matter content of the present study in pineapple plantation corroborates with the studies of Hendrix et al. [126] at 10 sites, which included conventional, nontillage agroecosystem, grass, meadows, and a mixed deciduous forest in the south eastern USA. Ghabbour and Shakir [127] reported that increased density and biomass of earthworms were associated with increase in organic carbon content of semiarid agricultural soils in Egypt. 
Recently, Dey and Chaudhuri [85] reported strong positive correlation between soil organic matter content and density of earthworm in pineapple plantation of West Tripura. Thus, there is little doubt that the availability of organic matter is one of the most important factors in influencing earthworm abundance.

According to Blanchart and Julka [81], maximum population density and species diversity occur within a range of $2.4 \%$ to $4.5 \%$ organic matter content. High earthworm diversity in low organic matter is probably due to the domination of more geophagous species in the pineapple agroecosystem (9 endogeic species). Faster organic matter decomposition rate at higher temperature under tropical conditions results in decreased litter availabilities and thus litter feeding epigeic and anecic earthworm populations tend to be depleted in tropical soils compared to those in temperate ones. Fragoso et al. [61] also advocated that earthworm communities of tropical agroecosystems are mostly composed of endogeic species of earthworms. Texture, nutrient status, and moisture conditions of soil probably determine functional categories of earthworms in an ecosystem [12].

\section{Conclusion}

Native endogeic earthworm with dominance of acidophilic species, Drawida assamensis, is a characteristic of pineapple agroecosystems in Tripura. The increasing activity of Drawida assamensis in pineapple plantation, with increasing age of plantations, suggests that individual plant species with its soil microclimatic conditions favor D. assamensis over the other species of earthworms. Vertical distribution of earthworms is greatly influenced by seasonal variation.

Species richness is a fundamental measurement of community and regional diversity. Species accumulation and sample-based rarefaction curves are very useful techniques in analyzing inventory completeness and species richness. Based on our experience, we recommend Chao 2 richness estimator to be applied in a particular investigation site, with nonasymptotic species richness, to indicate the number of earthworm species yet to be discovered.

Soil temperature and $\mathrm{pH}$ are identified as the major regulatory factors for earthworm distribution under the pineapple agroecosystems.

\section{Conflict of Interests}

The authors declare that there is no conflict of interests regarding the publication of this paper.

\section{Acknowledgment}

The authors express their sincere thanks to the Head of the Department of Zoology, Maharaja Bir Bikram College, Agartala, for providing laboratory facilities.

\section{References}

[1] P. Lavelle, T. Decaëns, M. Aubert et al., "Soil invertebrates and ecosystem services," European Journal of Soil Biology, vol. 42, supplement 1, pp. S3-S15, 2006.
[2] A. Don, B. Steinberg, I. Schöning et al., “Organic carbon sequestration in earthworm burrows," Soil Biology \& Biochemistry, vol. 40, no. 7, pp. 1803-1812, 2008.

[3] C. Fragoso and P. Lavelle, "Earthworm communities of tropical rain forests," Soil Biology \& Biochemistry, vol. 24, no. 12, pp. 1397-1408, 1992.

[4] T. Bhadauria, P. S. Ramakrishnan, and K. N. Srivastava, "Diversity and distribution of endemic and exotic earthworms in natural and regenerating ecosystems in the central Himalayas, India," Soil Biology \& Biochemistry, vol. 32, no. 14, pp. 20452054, 2000.

[5] P. S. Chaudhuri and S. Nath, "Community structure of earthworms under rubber plantations and mixed forests in Tripura, India," Journal of Environmental Biology, vol. 32, no. 5, pp. 537541, 2011.

[6] G. Gonzalez, X. Zou, and S. Borges, "Earthworm abundance and species composition in abandoned tropical cropland: comparison of tree plantation and secondary forests," Pedobiologia, vol. 40, pp. 385-391, 1996.

[7] G. González, X. Zou, A. Sabat, and N. Fetcher, "Earthworm abundance and distribution pattern in contrasting plant communities within a tropical wet forest in Puerto Rico," Caribbean Journal of Science, vol. 35, no. 1-2, pp. 93-100, 1999.

[8] J. B. Kotcon, "Population dynamics of earthworms in organic farming systems," in Biology of Earthworms, A. Karaca, Ed., vol. 24 of Soil Biology, pp. 299-310, Springer, Berlin, Germany, 2011.

[9] D. P. Bartholomew, R. E. Paull, and K. G. Rohrback, The Pineapple: Botany, Production and Used, CABI Publishing, Wallingford, UK, 2003.

[10] C. Kole, Wild Crop Relatives: Genomic and Breeding Resources. Tropical and Subtropical Fruits, Springer, Berlin, Germany, 2011.

[11] C. A. Edwards and P. J. Bohlen, Biology and Ecology of Earthworms, Chapman and Hall, London, UK, 1996.

[12] P. S. Chaudhuri, S. Nath, and R. Paliwal, "Earthworm population of rubber plantations (Hevea brasiliensis) in Tripura, India," Tropical Ecology, vol. 49, no. 2, pp. 225-234, 2008.

[13] P. S. Chaudhuri, S. Nath, S. Bhattacharjee, and R. Paliwal, "Biomass, density of earthworm under rubber plantation (Hevea brasilensis) in Tripura, India," The Bioscan, vol. 4, no. 3, pp. 475-479, 2009.

[14] P. S. Chaudhuri, S. Nath, T. K. Pal, and T. K. Dey, "Earthworm casting activities under rubber plantations (Hevea brasilensis) in Tripura, India," World Journal of Agricultural Sciences, vol. 5, no. 4, pp. 515-521, 2009.

[15] R. D. Kale and N. Karmegam, "The role of earthworms in tropics with emphasis on Indian ecosystems," Applied and Environmental Soil Science, vol. 2010, Article ID 414356, 16 pages, 2010.

[16] I. A. Najar and A. B. Khan, "Earthworm communities of Kashmir Valley, India," Tropical Ecology, vol. 52, no. 2, pp. 151162,2011

[17] M. C. Dash and K. G. Saxena, "Earthworms in the Himalaya and Western Ghats region of India: a review," The Bioscan, vol. 7, no. 1, pp. 1-12, 2012.

[18] S. C. Tiwari, B. K. Tiwari, and R. R. Mishra, "Relationship between seasonal populations of earthworms and abiotic factors in pineapple plantations," Proceedings of the National Academy of Sciences, India Section B: Biological Sciences, vol. 62, no. 2, pp. 223-226, 1992. 
[19] N. O. K. Mainoo, S. Barrington, J. K. Whalen, and L. Sampedro, "Pilot-scale vermicomposting of pineapple wastes with earthworms native to Accra, Ghana," Bioresource Technology, vol. 100, no. 23, pp. 5872-5875, 2009.

[20] J. M. Anderson and J. S. I. Ingram, Tropical Soil Biology and Fertility-A Handbook of Methods, CAB International, Wallingford, UK, 2nd edition, 1993.

[21] A. Dey and P. S. Chaudhuri, "Quantifying earthworm species richness in the pineapple and mixed fruit plantations of West Tripura, India-a non-parametric approach," European Journal of Soil Biology, vol. 59, pp. 31-35, 2013.

[22] D. E. Bignell, R. Constantino, C. Csuzdi et al., "Macrofauna," in A Handbook of Tropical Soil Biology: Sampling and Characterization of Below-Ground Biodiversity, F. M. S. Moreira, E. J. Huising, and D. E. Bignell, Eds., pp. 43-58, Earthscan, Taylor \& Francis, 2008.

[23] G. E. Gates, Burmese Earthworms. An Introduction to the Systematics and Biology of Megadrile Oligochaetes with Special Reference to Southeast Asia, vol. 62 of Transactions of the American Philosophical Society, American Philosophical Society, Philadelphia, Pa, USA, 1972.

[24] J. M. Julka, The Fauna of India and Adjacent Countries: Megadrile Oligochaeta (Earthworms), Zoological Survey of India, Kolkata, India, 1988.

[25] M. C. Dash and S. P. Dash, Fundamentals of Ecology, Tata McGraw-Hill Education Pvt., New Delhi, India, 2009.

[26] P. F. Hendrix and P. J. Bohlen, "Exotic earthworm invasions in North America: ecological and policy implications," BioScience, vol. 52, no. 9, pp. 801-811, 2002.

[27] J. Valckx, G. Govers, M. Hermy, and B. Muys, "Optimizing earthworm sampling in ecosystems," in Biology of Earthworms, A. Karaca, Ed., Soil Biology, pp. 19-38, Springer, London, UK, 2011.

[28] R. K. Colwell and J. A. Coddington, "Estimating terrestrial biodiversity through extrapolation," Philosophical transactions of the Royal Society of London Series: B, vol. 345, no. 1311, pp. 101-118, 1994.

[29] J. A. Coddington, L. H. Young, and F. A. Coyle, "Estimating spider species richness in a southern Appalachian cove hardwood forest," Journal of Arachnology, vol. 24, no. 2, pp. 111-128, 1996.

[30] A. E. Magurran, Measuring Biological Diversity, Blackwell Science, Oxford, UK, 2004.

[31] R. K. Colwell, EstimateS: Statistical Estimation of Species Richness and Shared Species from Samples, Version 8.2.0, 2009, http:// purl.oclc.org/estimates.

[32] Microcal Software, “Origin 6.0 Professional," 1999, http://www .microcal.com.

[33] N. J. Gotelli and R. K. Colwell, "Estimating species richness," in Biological Diversity: Frontiers in Measurement and Assessment, A. E. Magurran and B. J. McGill, Eds., Oxford University Press, London, UK, 2010.

[34] A. Chao, "Non-parametric estimation of the number of classes in a population," Scandinavian Journal of Statistics, vol. 11, no. 4, pp. 265-270, 1984.

[35] A. Chao, W.-H. Hwang, Y.-C. Chen, and C.-Y. Kuo, "Estimating the number of shared species in two communities," Statistica Sinica, vol. 10, no. 1, pp. 227-246, 2000.

[36] K. P. Burnham and W. S. Overton, "Estimation of the size of a closed population when capture probabilities vary among animals," Biometrika, vol. 65, no. 3, pp. 625-633, 1978.
[37] K. P. Burnham and P. S. Overton, "Robust estimation of population size when capture probabilities vary among animals," Ecology, vol. 60, no. 5, pp. 927-936, 1979.

[38] A. Chao, "Estimating the population size for capture-recapture data with unequal catchability," Biometrics, vol. 43, no. 4, pp. 783-791, 1987.

[39] E. P. Smith and G. van Belle, "Nonparametric estimation of species richness," Biometrics, vol. 40, no. 1, pp. 119-129, 1984.

[40] J. G. Raaijmakers, "Statistical analysis of the Michaelis-MENten equation," Biometrics, vol. 43, no. 4, pp. 793-803, 1987.

[41] D. S. Toti, F. A. Coyle, and J. A. Miller, "A structured inventory of Appalachian grass bald and heath bald spider assemblages and a test of species richness estimator performance," Journal of Arachnology, vol. 28, no. 3, pp. 329-345, 2000.

[42] R. K. Colwell, EstimateS: Statistical Estimation of Species Richness and Shared Species from Samples, Version 7.5, 2006, http://viceroy.eeb.uconn.edu/estimates.

[43] J. H. Connell, "Territorial behavior and dispersion in some marine invertebrates," Researches on Population Ecology, vol. 5, no. 2, pp. 87-101, 1963.

[44] G. Sileshi, "The excess-zero problem in soil animal count data and choice of appropriate models for statistical inference," Pedobiologia, vol. 52, no. 1, pp. 1-17, 2008.

[45] A. N. Kolmogorov, "Sulla determinazione empirica di una legge di distribuzione," Giornale dell'Istituto Italiano degli Attuari, vol. 4, pp. 83-91, 1933.

[46] N. V. Smirnov, "Sur les écarts de la courbe de distribution empirique," Recueil Mathematics NS, vol. 6, no. 1, pp. 3-26, 1939.

[47] N. V. Smirnov, "On the estimation of the discrepancy between empirical curves of distribution for two independent samples," Bulletin of Moscow University, vol. 2, pp. 3-16, 1939.

[48] M. A. Stephens, "EDF statistics for goodness of fit and some comparisons," Journal of the American Statistical Association, vol. 69, no. 347, pp. 730-737, 1974.

[49] E. C. Pielou, Mathematical Ecology, John Wiley \& Sons, New York, NY, USA, 1977.

[50] M. Morisita, "Measuring of the dispersion of individual and analysis of distribution patterns," Member Faculty of Science, Kyushu University, Series E (Biological Science), vol. 2, pp. 215235, 1959.

[51] A. Walkley and I. A. Black, "An examination of the Degtjareff method for determining soil organic matter, and a proposed modification of the chromic acid titration method," Soil Science, vol. 37, no. 1, pp. 29-38, 1934.

[52] J. A. Daji, A Text Book of Soil Science, Media Promoters and Publishers, Mumbai, India, 1996.

[53] B. Heider, M. S. Andersson, and R. Schultze-Kraft, "RAPD variation among North Vietnamese Flemingia macrophylla (Willd.) Kuntze ex Merr. accessions," Biodiversity and Conservation, vol. 16, no. 6, pp. 1617-1631, 2007.

[54] J. F. Hair Jr., R. E. Anderson, R. L. Tatham, and W. C. Black, Multivariate Data Analysis with Readings, Macmillan, New York, NY, USA, 1992.

[55] B. F. J. Manly, Multivariate Statistical Methods, Chapman \& Hall, London, UK, 1989.

[56] J. F. Hair Jr., R. E. Anderson, R. L. Tatham, and W. C. Black, Multivariate Data Analysis, Prentice Hall, London, UK, 5th edition, 1998.

[57] P. E. Green and J. D. Carroll, Mathematical Tools for Applied Multivariate Analysis, Academic Press, New York, NY, USA, 1978. 
[58] C. J. F. ter Braak and P. Smilauer, CANOCO Reference Manual and CanoDraw for Windows User's Guide: Software for Canonical Community Ordination (Version 4.5), Microcomputer Power, Ithaca, NY, USA, 2002.

[59] W. Fannes, D. De Bakker, K. Loosveldt, and R. Jocqué, "Estimating the diversity of arboreal oonopid spider assemblages (Araneae, Oonopidae) at Afrotropical sites," Journal of Arachnology, vol. 36, no. 2, pp. 322-330, 2008.

[60] M. Unterseher, M. Schnittler, C. Dormann, and A. Sickert, "Application of species richness estimators for the assessment of fungal diversity," FEMS Microbiology Letters, vol. 282, no. 2, pp. 205-213, 2008.

[61] C. Fragoso, P. Lavelle, E. Blanchart et al., "Earthworm communities of tropical agro ecosystem: origin, structure and influence of management practices," in Earthworm Management in Tropical Agro Ecosystems, P. Lavelle, L. Brusaard, and P. Hendrix, Eds., CAB International, Wallingford, UK, 1999.

[62] A. Feijoo, A. F. Carvajal, M. C. Zúñiga, H. Quintero, and C. Fragoso, "Diversity and abundance of earthworms in land use systems in Central-Western Colombia," Pedobiologia, vol. 54, pp. S69-S75, 2011.

[63] K. R. Halder, "Oligochaeta: earthworm," in State Fauna Series 7: Fauna of Tripura, Part 4, Zoological Survey of India, Calcutta, India, 2000.

[64] P. S. Chaudhuri and G. Bhattacharjee, "Earthworms of Tripura (India)," Ecology, Environment \& Conservation, vol. 11, no. 2, pp. 295-301, 2005.

[65] S. Nath, Earthworm resources in the rubber plantations of Tripura with special reference to their ecological characteristics [Ph.D. thesis], Tripura University, Agartala, India, 2012.

[66] J. W. Reynolds, J. M. Julka, and M. N. Khan, "Additional earthworm records from Bangladesh (Oligochaeta: Glossoscolecidae, Megascolecidae, Moniligastridae, Ocnerodrilidae and Octochaetidae)," Megadrilogica, vol. 6, no. 6, pp. 51-62, 1995.

[67] J. M. Julka, "Studies on the earthworm collected during the Daphabum expedition in Arunachal Pradesh, India," Records of Zoological Survey of India, vol. 69, pp. 229-239, 1976.

[68] K. R. Halder, "Oligochaeta: earthworm," in State Fauna Series 4: Fauna of Meghalaya, Part 9, Zoological Survey of India, Kolkata, India, 1999.

[69] H. Lalthanzara and S. N. Ramanujam, "Effect of fertilizer (NPK) on earthworm population in the agro-forestry system of Mizoram, India," Science Vision, vol. 10, no. 4, pp. 159-167, 2010.

[70] H. Lalthanzara and S. N. Ramanujam, "Vertical distribution of earthworms in agro-forestry system of Mizoram, India," in Biology and Ecology of Tropical Earthworms, P. S. Chaudhuri and S. M. Singh, Eds., pp. 125-140, Discovery Publishing House, New Delhi, India, 2014.

[71] J. Illig, R. A. Norton, S. Scheu, and M. Maraun, "Density and community structure of soil- and bark-dwelling microarthropods along an altitudinal gradient in a tropical montane rainforest," Experimental and Applied Acarology, vol. 52, no. 1, pp. 49-62, 2010.

[72] O. F. Palin, P. Eggleton, Y. Malhi, C. A. J. Girardin, A. RozasDávila, and C. L. Parr, "Termite diversity along an AmazonAndes elevation Gradient, Peru," Biotropica, vol. 43, no. 1, pp. 100-107, 2011.

[73] C. Salomé, C. Guenat, G. Bullinger-Weber, J.-M. Gobat, and R.-C. L. Bayon, "Earthworm communities in alluvial forests; influence of altitude, vegetation stages and soil parameters," Pedobiologia, vol. 54, supplement, pp. S89-S98, 2011.
[74] D. Verma and Sweta, "Earthworm resources of Western Himalayan region, India," International Journal of Soil Science, vol. 6, no. 2, pp. 124-133, 2011.

[75] P. S. Chaudhuri and A. Dey, "Earthworm communities in the pineapple (Ananus comosus) and mixed fruit plantations of West Tripura, India," Proceedings of the Zoological Society, vol. 66, no. 2, pp. 105-118, 2013.

[76] A. Dey and P. S. Chaudhuri, "Earthworm community structure of pineapple (Ananas comosus) plantations under monoculture and mixed culture in West Tripura, India," Tropical Ecology, vol. 55, no. 1, pp. 1-17, 2014.

[77] S. Bhattacharjee, Impact of rubber plantations on the earthworm communities of West Tripura, India [Ph.D. thesis], Tripura University, Agartala, India, 2013.

[78] A. Dey, Ecological studies on earthworms of pineapple (Ananas comosus) plantation with special reference to their community characteristics [Ph.D. thesis], Tripura University, Agartala, India, 2014.

[79] M. Sarlo, "Individual tree species effects on earthworm biomass in a tropical plantation in Panama," Caribbean Journal of Science, vol. 42, no. 3, pp. 419-427, 2006.

[80] A. Dey, S. Nath, and P. S. Chaudhuri, "Impact of monoculture (rubber and pineapple) practice on the community characteristics of earthworms in West Tripura (India)," NeBIO, vol. 3, no. 1, pp. 53-58, 2012.

[81] E. Blanchart and J. M. Julka, "Influence of forest disturbance on earthworm (Oligochaeta) communities in the Western Ghats (South India)," Soil Biology \& Biochemistry, vol. 29, no. 3-4, pp. 303-306, 1997.

[82] T. Bhadauria and P. S. Ramakrishnan, "Population dynamics of earthworms and their activity in forest ecosystems of north-east India," Journal of Tropical Ecology, vol. 7, no. 3, pp. 305-318, 1991.

[83] C. X. Mao, R. K. Colwell, and J. Chang, "Estimating the species accumulation curve using mixtures," Biometrics, vol. 61, no. 2, pp. 433-441, 2005.

[84] A. Dey and P. S. Chaudhuri, "Community characteristics of earthworms in different age groups of pineapple plantations (Ananus comosus) in West Tripura, India," Asian and Australasian Journal of Plant Science \& Biotechnology, vol. 6, no. 1, pp. 67-75, 2012.

[85] A. Dey and P. S. Chaudhuri, "Density, diversity and distribution of earthworms in pineapple plantation (Ananus comosus) plots of different ages in West Tripura, India," in Climate Change and Biodiversity, P. K. Bharti and A. Chauhan, Eds., Discovery Publishing House, New Delhi, India, 2013.

[86] C. X. Mao and R. K. Colwell, "Estimation of species richness: mixture models, the role of rare species, and inferential challenges," Ecology, vol. 86, pp. 1143-1153, 2005.

[87] J. Hortal, P. A. V. Borges, and C. Gaspar, "Evaluating the performance of species richness estimators: sensitivity to sample grain size," Journal of Animal Ecology, vol. 75, no. 1, pp. 274-287, 2006.

[88] A. Chao, R. K. Colwell, C.-W. Lin, and N. J. Gotelli, "Sufficient sampling for asymptotic minimum species richness estimators," Ecology, vol. 90, no. 4, pp. 1125-1133, 2009.

[89] B. A. Walther and J. L. Moore, "The concepts of bias, precision and accuracy, and their use in testing the performance of species richness estimators, with a literature review of estimator performance," Ecography, vol. 28, no. 6, pp. 815-829, 2005.

[90] A. E. Magurran, S. R. Baillie, S. T. Buckland et al., "Longterm datasets in biodiversity research and monitoring: assessing change in ecological communities through time," Trends in Ecology \& Evolution, vol. 25, no. 10, pp. 574-582, 2010. 
[91] J. B. Hughes, J. J. Hellmann, T. H. Ricketts, and B. J. M. Bohannan, "Counting the uncountable: statistical approaches to estimating microbial diversity," Applied and Environmental Microbiology, vol. 67, no. 10, pp. 4399-4406, 2001.

[92] B. J. M. Bohannan and J. Hughes, "New approaches to analyzing microbial biodiversity data," Current Opinion in Microbiology, vol. 6, no. 3, pp. 282-287, 2003.

[93] J. P. Rossi and P. Lavelle, "Earthworm aggregation in the Savannas of Lamto (Côte d' Noire)," Applied Soil Ecology, vol. 7, no. 2, pp. 195-199, 1998.

[94] M. Lloyd, "Mean crowding," The Journal of Animal Ecology, vol. 36, no. 1, pp. 1-30, 1967.

[95] J. J. Jiménez, J.-P. Rossi, and P. Lavelle, "Spatial distribution of earthworms in acid-soil savannas of the eastern plains of Colombia," Applied Soil Ecology, vol. 17, no. 3, pp. 267-278, 2001.

[96] J.-P. Rossi, "Clusters in earthworm spatial distribution," Pedobiologia, vol. 47, no. 5-6, pp. 490-496, 2003.

[97] C. H. Ettema and D. A. Wardle, "Spatial soil ecology," Trends in Ecology \& Evolution, vol. 17, no. 4, pp. 177-183, 2002.

[98] J. J. Jiménez and T. Decaëns, "Vertical distribution of earthworms in grassland soils of the Colombian Llanos," Biology \& Fertility of Soils, vol. 32, no. 6, pp. 463-473, 2000.

[99] P. Lavelle, Les Vers de Terre de la Savane de Lamto, Côte d'Ivoire: Peuplements, Populations et Fonctions dans l'écosystème, vol. 12, Publications du laborotoire de Zoologie de l'Ecole Normale Superieure, 1978.

[100] A. Nemeth and R. Herrera, "Earthworm populations in a Venezuelan tropical rain forest," Pedobiologia, vol. 23, no. 6, pp. 437-443, 1982.

[101] C. Fragoso, Les peulements vers de terre dans I'est et sud'est du Mexique [Ph.D. thesis], Université Paris, Paris, France, 1993.

[102] T. G. Piearce, "Functional morphology of lumbricid earthworms, with special reference to locomotion," Journal of Natural History, vol. 17, no. 1, pp. 95-111, 2007.

[103] B. R. Kaushal, S. Kalia, and S. P. Bisht, "Growth and cocoon production by the earthworm Drawida nepalensis (Oligochaeta: Moniligastridae) in oak and pine litter," Pedobiologia, vol. 39, no. 5, pp. 417-422, 1995.

[104] R. Bisht, H. Pandey, D. Bharti, and B. R. Kaushal, "Population dynamics of earthworms (Oligochaeta) in cultivated soils of central Himalayan tarai region," Tropical Ecology, vol. 44, pp. 229-234, 2003.

[105] E. Doblas-Miranda, F. Sánchez-Piñero, and A. GonzálezMegías, "Different microhabitats affect soil macro-invertebrate assemblages in a Mediterranean arid ecosystem," Applied Soil Ecology, vol. 41, no. 3, pp. 329-335, 2009.

[106] M. V. Reddy and M. Pasha, "Influence of rainfall, temperature and somes oil physico-chemical variables on seasonal population structure and vertical distribution of earthworms in two semi-arid tropical grassland soils," International Journal of Biometeorology, vol. 37, no. 1, pp. 19-26, 1993.

[107] G. Baker, J. Buckerfield, R. Grey-Gardner, R. Merry, and B. Doube, "The abundance and diversity of earthworms in pasture soils in the fleurieu peninsula, south australia," Soil Biology \& Biochemistry, vol. 24, no. 12, pp. 1389-1395, 1992.

[108] P. S. Chaudhuri and S. Bhattacharjee, "Reproductive biology of eight tropical earthworm species of rubber plantations in tripura, india," Tropical Ecology, vol. 52, no. 1, pp. 49-60, 2011.

[109] G. Bhattacharjee and P. S. Chaudhuri, "Cocoon production, morphology, hatching pattern and fecundity in seven tropical earthworm species-a laboratory-based investigation," Journal of Biosciences, vol. 27, no. 3, pp. 283-294, 2002.
[110] T. A. McCredie, C. A. Parker, and I. Abbott, "Population dynamics of the earthworm Aporrectodea trapezoides (Annelida: Lumbricidae) in a Western Australian pasture soil," Biology \& Fertility of Soils, vol. 12, no. 4, pp. 285-289, 1992.

[111] C. Fragoso and P. Lavelle, "The earthworm community of a tropical rain forest," in On Earthworms, A. M. BonviciniPagliani and P. Omodeo, Eds., Mucchi Editore, Modena, Italy, 1987.

[112] C. Gilot, P. Lavelle, E. Blanchart, J. Keli, P. Kouassi, and G. Guillaume, "Biological activity of soil under rubber plantations in Cote d'Ivoire," Acta Zoologica Fennica, vol. 196, pp. 186-189, 1995.

[113] L. M. C. Mboukou-Kimbatsa and F. Bernhard-Reversat, "Effect of exotic tree plantations on invertebrate soil macro fauna," in Effect of Exotic Tree Plantations on Plant Diversity and Biological Soil Fertility in Congo, Svana: With Special Reference to Eucalyptus, F. Bernhard-Reversat, Ed., Centre for International Forestry Research, Bogor, Indonesia, 2001.

[114] P. S. Chaudhuri and S. Bhattacharjee, "Impact of rubber plantation on the earthworm communities in Tripura (India)," in Earthworm Ecology and Environment, S. M. Singh, Ed., International Book Distribution Co, Lucknow, India, 2009.

[115] T. Decaëns, F. Bureau, and P. Margerie, "Earthworm communities in a wet agricultural landscape of the Seine Valley (Upper Normandy, France)," Pedobiologia, vol. 47, no. 5-6, pp. 479-489, 2003.

[116] S. H. Shakir and D. L. Dindal, "Density and biomass of earthworms in forest and herbaceous microecosystems in central New York, North America," Soil Biology \& Biochemistry, vol. 29, no. 3-4, pp. 275-285, 1997.

[117] J. K. Whalen, "Spatial and temporal distribution of earthworm patches in corn field, hayfield and forest systems of southwestern Quebec, Canada," Applied Soil Ecology, vol. 27, no. 2, pp.143151, 2004.

[118] J. P. Rossi, E. Huerta, C. Fragoso, and P. Lavelle, "Soil properties inside earthworm patches and gaps in a tropical grassland (la Mancha, Veracruz, Mexico)," European Journal of Soil Biology, vol. 42, no. 1, pp. S284-S288, 2006.

[119] P. S. Chaudhuri, A. Dey, G. Bhattacharjee, and S. Nath, "Earthworm diversity in Tripura-present status," Science \& Culture, vol. 78, no. 7-8, pp. 343-346, 2012.

[120] C. A. Edwards, "The importance of earthworms as key representatives of the soil fauna," in Earthworm Ecology, C. A. Edwards, Ed., St. Lucie Press, Boca Raton, Fla, USA, 2004.

[121] P. Lavelle, L. Brussard, and P. Hendrix, Earthworm Management in Tropical Agroecosystems, CABI Publishing, New York, NY, USA, 1999.

[122] G. A. Spiers, D. Gagnon, G. E. Nason, E. C. Packee, and J. D. Lousier, "Effects and importance of indigenous earthworms on decomposition and nutrient cycling in coastal forest ecosystems," Canadian Journal of Forest Research, vol. 16, no. 5, pp. 983-989, 1986.

[123] G. Bachelier, La Vie Animale dans les Sols, Orston, Paris, France, 1963.

[124] H. Staaf, "Foliage litter turnover and earthworm populations in three beech forests of contrasting soil and vegetation types," Oecologia, vol. 72, no. 1, pp. 58-64, 1987.

[125] I. A. Najar and A. B. Khan, "Factors affecting distribution of earthworms in Kashmir Valley: a multivariate statistical approach," Proceedings of the Zoological Society, vol. 67, no. 2, pp. 126-135, 2014. 
[126] P. F. Hendrix, B. R. Mueller, R. R. Bruce, G. W. Langdale, and R. W. Parmelee, "Abundance and distribution of earthworms in relation to landscape factors on the Georgia Piedmont, U.S.A," Soil Biology \& Biochemistry, vol. 24, no. 12, pp. 1357-1361, 1992.

[127] S. I. Ghabbour and S. H. Shakir, "Population density and biomass of earthworms in agro-ecosystems of the Mariut coastal desert region," Pedobiologia, vol. 23, pp. 189-198, 1982. 

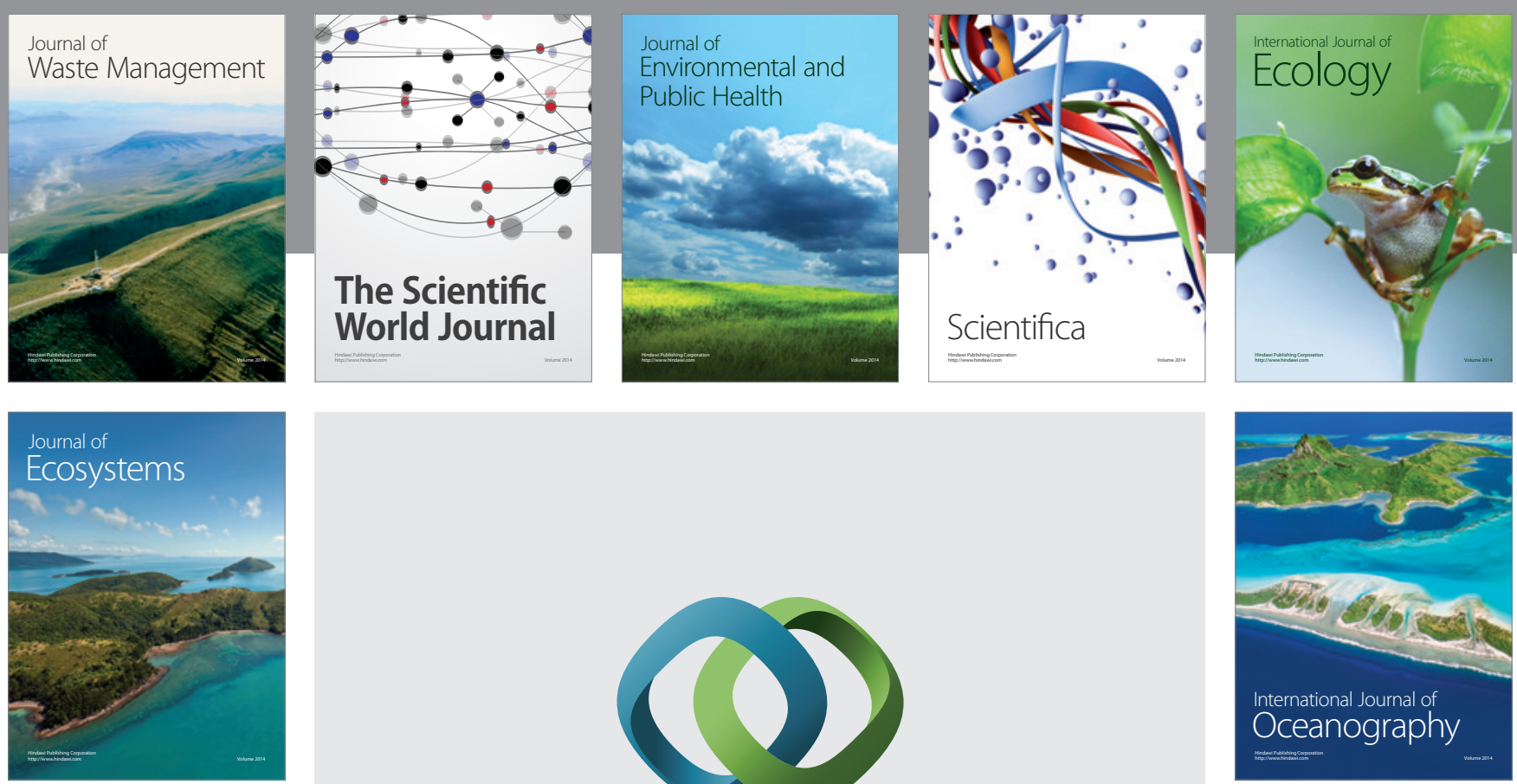

The Scientific World Journal
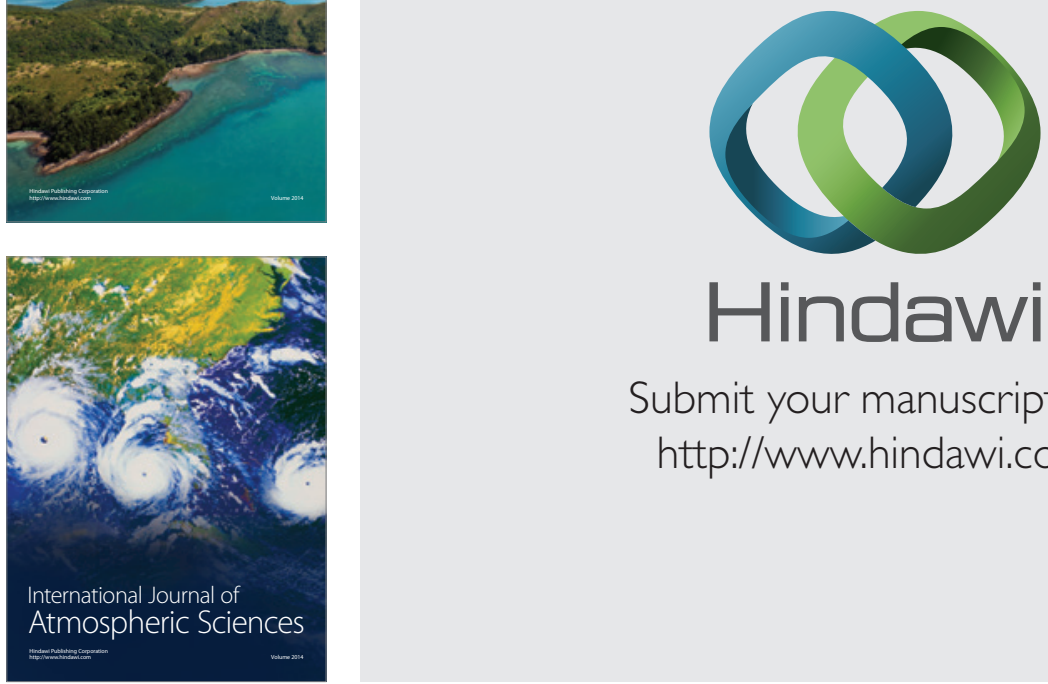

\section{Hindawi}

Submit your manuscripts at

http://www.hindawi.com
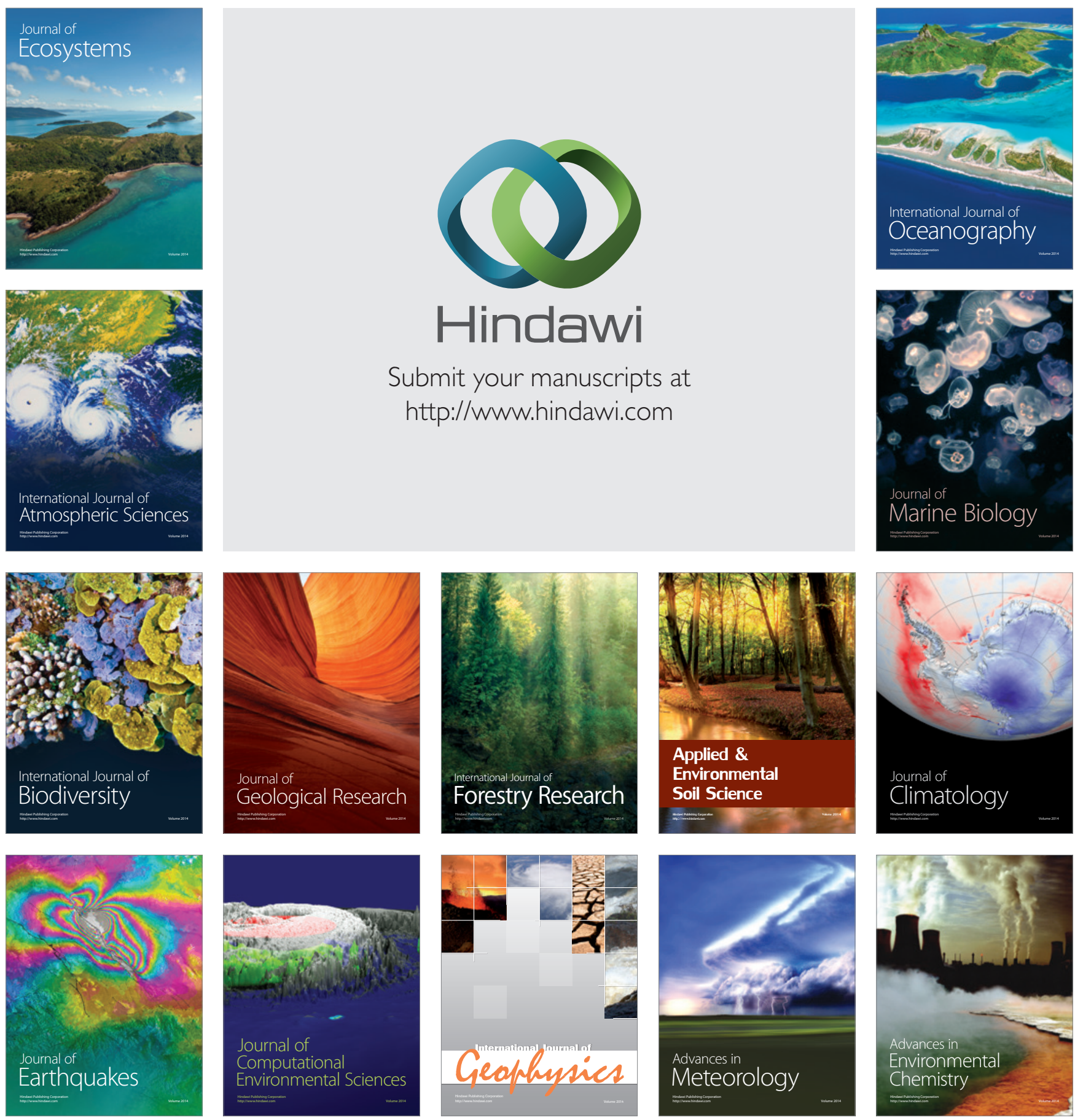